CNS Drugs 2013; 24 (5)

Review Article

Running Header: Plant-Based Anxiolytic Psychopharmacology

\title{
Plant-Based Medicines for Anxiety Disorders, Part 2: A Review of Clinical Studies with Supporting Preclinical Evidence
}

Jerome Sarris, ${ }^{1,2}$ Erica McIntyre ${ }^{3}$ and David A. Camfield ${ }^{2}$

${ }^{1}$ Department of Psychiatry, Faculty of Medicine, University of Melbourne, Richmond, VIC, Australia

${ }^{2}$ The Centre for Human Psychopharmacology, Swinburne University of Technology, Melbourne, VIC, Australia

${ }^{3}$ School of Psychology, Charles Sturt University, Wagga Wagga, NSW, Australia

Correspondence: Jerome Sarris, Department of Psychiatry and The Melbourne Clinic, University of Melbourne, 2 Salisbury Street, Richmond, VIC 3121, Australia.

Email: jsarris@unimelb.edu.au,

\section{Acknowledgements}

Dr Jerome Sarris is funded by an Australian National Health \& Medical Research Council fellowship (NHMRC funding ID 628875), in a strategic partnership with The University of Melbourne, The Centre for Human Psychopharmacology at the Swinburne University of Technology. Jerome Sarris, Erica McIntyre and David A. Camfield have no conflicts of interest that are directly relevant to the content of this article. 


\section{Abstract}

Research in the area of herbal psychopharmacology has revealed a variety of promising medicines that may provide benefit in the treatment of general anxiety and specific anxiety disorders. However, a comprehensive review of plant-based anxiolytics has been absent to date. Thus, our aim was to provide a comprehensive narrative review of plant-based medicines that have clinical and/or preclinical evidence of anxiolytic activity. We present the article in two parts. In part one, we reviewed herbal medicines for which only preclinical investigations for anxiolytic activity have been performed. In this current article (part two), we review herbal medicines for which there have been both preclinical and clinical investigations for anxiolytic activity. A search of MEDLINE (PubMed), CINAHL, Scopus and the Cochrane Library databases was conducted (up to 28 October 2012) for English language papers using the search terms 'anxiety' OR 'anxiety disorder' OR 'generalized anxiety disorder' OR 'social phobia' OR 'post-traumatic stress disorder' OR 'panic disorder' OR 'agoraphobia' OR 'obsessive compulsive disorder' in combination with the search terms 'Herb*' OR 'Medicinal Plants' OR 'Botanical Medicine' OR 'Chinese herb*', in addition to individual herbal medicines. This search of the literature revealed 1,525 papers, of which 53 plants were included in the review (having at least one study using the whole plant extract). Of these plants, 21 had human clinical trial evidence (reviewed here in part two), with the other 32 having solely preclinical evidence (reviewed in part one). Support for efficacy was found for chronic use (i.e. greater than one day) of the following herbs in treating a range of anxiety disorders in human clinical trials: Piper methysticum, Matricaria recutita, Ginkgo biloba, Scutellaria lateriflora, Silybum marianum, Passiflora incarnata, Withania somniferum, Galphimia glauca, Centella asiatica, Rhodiola rosea, Echinacea spp., Melissa officinalis and Echium amoenum. For several of the plants studied, conclusions need to be tempered due to methodological issues such as small sample sizes, brief intervention durations and nonreplication. Current evidence does not support Hypericum perforatum or Valeriana spp. for any anxiety disorder. Support for efficacy in regard to acute anxiolytic activity was found for Centella asiatica, Salvia spp., Melissa officinalis, Passiflora incarnata and Citrus aurantium. Bacopa monnieri has shown anxiolytic effects in people with cognitive decline. The therapeutic application of psychotropic plant-based treatments for anxiety disorders is also discussed, specifically Psychotria viridis and Banisteriopsis caarti (ayahuasca), Psilocybe spp. and cannabinol-enriched (low tetrahydrocannabinol $\left(\Delta^{9}-\mathrm{THC}\right)$ ) Cannabis spp. 


\section{Introduction}

Generalized acute anxiety, and specific anxiety disorders such as generalized anxiety disorder (GAD), social phobia (SP), obsessive-compulsive disorder (OCD), panic disorder (PD) and post-traumatic stress disorder (PTSD) present a challenge for clinicians (1). Although conventional pharmacotherapies and psychological interventions are front-line approaches, plant-based medicines may offer an additional safe and effective treatment option. As detailed in part one of this review (2), phytotherapeutic interventions that may benefit anxiety disorders are classed as 'anxiolytics', and usually have effects on the GABA system (3) either via inducing ionic channel transmission by voltage-gated blockage, or through alteration of membrane structures (4), or less commonly via binding with benzodiazepine receptor sites (e.g., GABA- $\alpha$ ) (5),, GABA-transaminase or glutamic acid decarboxylase inhibition (6) or interactions with several monoamines.

Although there are general reviews in the area (7-9), there is currently no specialized review comprehensively detailing both preclinical and clinical evidence for an expansive list of psychotropic plant medicines with anxiolytic activity. In this two-part paper, we provide a comprehensive review of plant-based medicines that have been assessed in human clinical trials (here in part two) and those for which only preclinical studies have been performed (part one) (2).

A search of the electronic databases MEDLINE (PubMed), CINAHL, Scopus and The Cochrane Library was conducted to review the evidence of plant-based medicines for treating anxiety. Databases were searched for English language papers containing in vitro, in vivo and clinical data of plant medicines studied specifically for anxiolytic activity. A comprehensive search was conducted for all available literature up to 28 October 2012 using the search terms 'anxiety' OR 'anxiety disorder' OR 'generalized anxiety disorder' OR 'social phobia' OR 'post-traumatic stress disorder' OR 'panic disorder' OR 'agoraphobia' OR 'obsessive compulsive disorder', combined with the search terms 'Herb*' OR 'Medicinal Plants' OR 'Botanical Medicine' OR 'Chinese herb*', in addition to individual plant medicines (both common names and Latin binomial names where appropriate). Papers that met the inclusion criteria of evidence for clinical efficacy were clinical trials (or meta-analyses in the case of kava, which has had many studies conducted) that consisted of acute or chronic human studies using plant-based medicines to treat anxiety, or involved preclinical methodology assessing an anxiolytic effect. No restriction was placed on sample size or methodology in respect to randomization, blinding or control. The term 'significant' was regarded as a $p$ value of $<0.05$. Effect sizes where available were calculated as Cohen's $d(0.2-0.5=$ small clinical effect, $0.5-0.8=$ medium clinical effect, $>0.8$ = large clinical effect). 
Our search of the literature revealed 1,525 papers germane to the area, of which the majority were omitted (not related to anxiety, used only isolated constituents, review papers), leaving clinical and preclinical studies for 53 plants to review. Of these, 21 had clinical evidence and are covered in this paper (see Table 1). The remaining 32 plants with solely preclinical evidence are discussed in part one of the article. For a full discussion of commonly used animal models of anxiety, which are mentioned in this section, readers are referred to part one. The following section is divided into two parts as follows: (1) anxiolytics with clinical evidence (presented in alphabetical order) and (2) psychotropic plant-based medicines with potential anxiolytic application. Psychotropic anxiolytics were included in a separate section due to the specific methodological challenges inherent to research involving these substances. It was deemed that their efficacy as potential anxiolytics was deserving of extended discussion.

Support for anxiolytic activity for the following multi-plant formulations was also found: Suanzaorentang (which contains Zizyphus jujuba) (10), Saiboku-to (11), Sho-ju-sen (12), Kamishoyo-san (13), Hange-koboku-to (13), Ting-chih-wan (14), Saikokaryukotsuboreito (15), Yokukansan (16), Xiao-yao-san (17) and Xiao-tan-jie-yu-fang (18). However, further discussion of these formulas is outside the scope of this review, which focuses on individual botanicals (with the exception of ayuhuasca, which has two major plant components).

\section{Plant-Based Medicines with Clinical Evidence of Anxiolytic Effects}

\subsection{Ashwagandha (Withania somnifera)}

The roots of ashwagandha have been classified in Ayurvedic medicine as a 'rasayana', a medicine used to enhance physical and mental performance (19). A preclinical study observed adaptogenic effects of ashwagandha given to rats over 21 days (25 or $50 \mathrm{mg} / \mathrm{kg}$, orally (p.o.)) in a stress-inducing procedure, via the attenuation of stress-related parameters (cortisol levels, mental depression, sexual dysfunction) (19). A methanolic extract of ashwagandha root was found to inhibit the specific binding of GABA ligands and enhanced the binding of flunitrazepam to their receptor sites, displaying a GABA-mimetic activity (20). In an in vivo study,

glycowithanolides (the purported active constituents) were administered at doses of 20 and 50 $\mathrm{mg} / \mathrm{kg}$ p.o. once daily for 5 days in rats. These constituents were discovered to induce an anxiolytic effect comparable to that produced by lorazepam, as measured by relevant models (elevated plus-maze (EPM), social interaction and feeding latency in an unfamiliar environment tests) (21). 
A 6-week, double-blind, randomized controlled trial (RCT) was conducted to evaluate the efficacy of an undefined ethanolic extract of ashwagandha (500 mg twice daily) in 39 patients with a range of International Classification of Diseases, Tenth Revision (ICD-10)-diagnosed anxiety disorders (22). Doses were titrated up to a maximum of $2.5 \mathrm{~g}$ twice daily or matching placebo (ten tablets) at the clinician's discretion. At week 6 , significantly more patients met response criteria in the ashwagandha group (88.2\%) compared with the placebo group (50\%). However, the 2.4-point difference on the Hamilton Anxiety Rating Scale (HAMA) in favour of ashwanganda was not statistically significant. Furthermore, clinician and patient ratings of improvement did not differ between groups. The extract was well tolerated and did not cause more adverse effects than placebo.

\subsection{Brahmi (Bacopa monnieri)}

Brahmi leaf has been used for over 3,000 years throughout the Indian subcontinent as a traditional Ayurvedic treatment for a range of CNS applications, being considered as a 'memory tonic' $(23,24)$. Preclinical research has demonstrated various CNS actions including nootropic, antidepressant, anxiolytic and antioxidant effects. Preclinical studies have also shown that brahmi modulates acetylcholine, dopamine, serotonin, and noradrenaline (norepinephrine) pathways (25), and increases protein kinase activity within the hippocampus (26). The key chemical constituent is regarded as bacoside $A$. In an isolated rat model, brahmi $(80 \mathrm{mg} / \mathrm{kg}$ p.o.) affected anxiolytic behavioural activity in the light/dark test and in the EPM (27). Brahmi was found not to cause any motor impairment. In addition to the majority of RCTs supporting the use of standardized extracts of brahmi as an effective memory enhancer (28), anxiolytic activity has also been shown. A double-blind RCT was conducted by Calabrese et al. (29), which explored the plants anxiolytic activity in addition to its cognitive-enhancing effects. The 12-week RCT (with an additional 6-week placebo run-in) involved 54 participants, aged 65 years or older with mild cognitive impairment and found that a standardized brahmi extract (300 $\mathrm{mg} /$ day) significantly reduced combined State and Trait anxiety scores on the State-Trait Anxiety Inventory (STAI). However, the clinical effect was very minor, and as the researchers used a one-tailed statistical analysis, this result would not be significant for a more appropriate two-tailed analysis. In another study, Stough et al. (30) found a significant reduction for the STAI-State anxiety score in a 12-week double-blind RCT, while primarily examining $300 \mathrm{mg}$ daily of brahmi (Keenmind) on cognitive function in 46 healthy participants.

\subsection{Bitter Orange (Citrus aurantium)}


The volatile oil 'bergamot' from bitter orange blossom has been used throughout Eurasia, and is popularised in the tea 'Earl Grey'. It is considered to exert psychological calming and bronchospasmolytic activity (31). Inhalation of the oil at $1.0 \%$ and $2.5 \%$ by weight to rats was compared with injection of diazepam in the EPM (32). Following bergamot oil inhalation, the percentage of time spent in the open arms of the EPM, as well as the number of head dips in a hole-board test, were significantly enhanced in a manner similar to diazepam. Both $2.5 \%$ of the essential oil and diazepam mitigated corticosterone response to acute EPM-provoked stress. One human study using whole bitter orange was located in our review. This acute double-blind, placebo-controlled study assessed the anxiolytic effects of an extract in 60 patients with preoperative anxiety (who were undergoing a minor lower limb operation) (33). Participants were randomized into two groups of 30 , receiving either a bitter orange blossom (petals and stamen) distillate $(1 \mathrm{~mL} / \mathrm{kg}$ ) standardized for linalool, total phenolic acids and flavonoids, or a saline solution control $(1 \mathrm{~mL} / \mathrm{kg}) 2 \mathrm{~h}$ before induction of general anaesthesia. Two hours postdose (just before the surgery) both the STAI-State and the Amsterdam Preoperative Anxiety and Information Scale scores were decreased for the bitter orange group compared with placebo. However, it should be noted that the authors did not display the Group $\times$ Time effect, thus the intervention may not have been significantly more efficacious than placebo.

\subsection{Chamomile (Matricaria recutita)}

The flowering tops of chamomile are widely consumed throughout Europe with a long history of traditional use for the herb's perceived calming effect, being commonly imbibed in the form of tea (34). The exact pharmacology behind the anxiolytic action of chamomile remains unclear. However, preclinical research has found a range of effects on the GABA system $(35,36)$. One of the regarded active constituents is the flavone apigenin, which has been demonstrated to be a benzodiazepine receptor ligand with anxiolytic activity $(37,38)$. However, it is argued that the receptor binding affinity is low (35), with one study demonstrating no interaction with the benzodiazepine receptor (39). Avallone and colleagues (35) found apigenin to have a sedative, but not an anxiolytic effect, and concluded that it is unlikely that the sedative effect is related to $\mathrm{GABA}_{\mathrm{A}}$ receptor activation. To date, only one in vitro study has explored the whole plant extract of chamomile (36). This study showed chamomile inhibited both glutamic acid decarboxylase and GABA-transaminase. However, as the inhibition of glutamic acid decarboxylase was greater than that of GABA-transaminase, CNS excitation may potentially result (36). This suggests that other mechanisms are also involved in chamomile's anxiolytic effects. A number of animal behavioural studies have explored the anxiolytic effects of isolated constituents of chamomile (35, 37-39); however, there has been no animal model using the whole plant extract to date. 
One 8-week double-blind RCT investigated the efficacy of chamomile extract standardized to $1.2 \%$ apigenin in reducing anxiety symptoms in individuals $(n=57)$ diagnosed with GAD (34). Chamomile was demonstrated to provide a statistically significant reduction in anxiety symptoms on the HAMA compared with placebo $(d=0.90)(34)$. This study used a dose escalation design, with doses ranging from 220 to $1,100 \mathrm{mg}$, varying according to response. Although this study provides evidence for efficacy of chamomile in reducing anxiety in some individuals with GAD, the most effective dosage remains uncertain. The authors also commented that chamomile was very well tolerated and found no increase in adverse events at higher doses, compared with placebo.

\subsection{Echinacea/Purple Cone Flower (Echinacea spp.)}

The flowers and roots of the Echinacea species have been used in traditional medicine in North America for immune system and inflammatory conditions, although emerging research is also revealing anxiolytic effects. A rat study using five types of echinacea extracts $(0.05-8 \mathrm{mg} / \mathrm{kg}$ intravenously (i.v.)) found that three out of five of these extracts decreased anxious behaviours in the EPM, social interaction and social avoidance tests (40). No locomotor suppressant effects were seen at any dose. Of interest, this effect was seen at lower doses of 1.5 and 2 $\mathrm{mg} / \mathrm{kg}$, and was not dose dependently related to alkylamides (although the extracts did contain these constituents). In a human trial by the same researchers, one or two tablets per day (20 or $40 \mathrm{mg}$ of concentrated echinacea extract) was administered in an open-label manner for 1 week (with a 3-day observation period) to a healthy sample of 31 adults with high STAI scores (41). The higher dose (two tablets per day) significantly decreased STAI scores over time within 3 days, remaining stable until day 7 (endpoint), and for the 2 weeks of follow-up observation. The lower dose (one tablet per day) was, however, not an effective anxiolytic. The anxiolytic effect of echinacea may be due to a range of lipophilic alkylamide constituents interacting with cannabinoid 2 receptors $(42,43)$. Further work using better methodology and larger samples are needed to endorse echinacea's application for anxiety.

\subsection{Iranian Borage (Echium amoenum)}

The flowers of Iranian borage contain a complex of constituents that includes pyrrolizidine alkaloids, and has been used as a traditional anxiolytic and thymoleptic plant medicine in Persia (44). One RCT investigated the efficacy and safety of Iranian borage in 44 patients with diagnosed OCD in a 6-week, double-blind RCT. Patients were assessed at baseline and during 
weeks 1, 2, 4 and 6 on the Yale-Brown Obsessive Compulsive Scale (Y-BOCS) and HAMA (45). Participants in both groups experienced only a slight reduction of OCD symptoms (five to six points on the Y-BOCS), with the Time $\times$ Treatment interaction ANOVA failing to meet statistical significance $(p=.068)$. The main effect for Treatment was significant, although this result is difficult to interpret considering that no adjustments were made for baseline Y-BOCS scores. However, independent t-tests revealed significantly lower Y-BOCS scores for Iranian borage in comparison to placebo at weeks 4 and 6 . In contrast, a significant Time $x$ Treatment interaction was observed for HAMA anxiety, with independent t-tests also revealing significant lower anxiety for Iranian borage in comparison to placebo at weeks 4 and 6, and a 6.5-point difference for Iranian borage over placebo at study endpoint. There was no significant difference between the two groups in terms of adverse effects, except for an increase in constipation in the placebo group (talcum powder tablets). Although no specific anti-OCD mechanism of action has been identified, a mice model has shown that the ethanolic extract of the flowers (50 mg/kg intraperitoneally (i.p.)) increased the percentage of time spent and the percentage of arm entries in the open arms of the EPM, and locomotor activity was also slightly inhibited (46).

\subsection{Galphimia (Galphimia glauca)}

In traditional Mexican and Central American cultures, the leaves and stem from the flowering bush galphimia have been used for a range of ailments including asthma, allergies and nervous disorders. The nor-seco-triterpene 'galphimine B' is regarded as an active constituent, which has been shown to interact with serotonergic transmission in the dorsal hippocampus in rats. This occurs by increasing the frequency of neuronal discharge in CA1 cells, and results in activation of serotonin $5-\mathrm{HT}_{1 \mathrm{~A}}$ receptors (47). The anxiolytic effects of a range of galphimia derivatives including galphimine B were evaluated in an EPM model. Administration of galaphimine $15 \mathrm{mg} / \mathrm{kg}$ i.p. (1 $\mathrm{h}$ before testing) caused an anxiolytic-like effect in the mice, significantly increasing the time spent in and number of entries into the open arm in the EPM (48). Further work by the group using a methanolic extract (standardized for galphimine $B$ content, $8.3 \mathrm{mg} / \mathrm{g}$ ) administered p.o., three times (24, 18 and $1 \mathrm{~h}$ before the test) in different doses $(125,250,500,1,000$ and $2,000 \mathrm{mg} / \mathrm{kg})$ found significant anxiolytic effects for mice in the EPM and the light-dark paradigm test. No effect was found, however, in the forced swimming test (49).

An aqueous extract of galphimia was administered to 153 patients with a DSM-IV diagnosis of GAD in a 4-week, positive-controlled, double-blind RCT (50). Patients with a HAMA score of 
over 19 were included. The positive control group received $1 \mathrm{mg}$ of the benzodiazepine lorazepam in capsule form twice daily and the galphimia group received $310 \mathrm{mg}$ of the herbal extract in capsule form twice daily (standardized to $0.348 \mathrm{mg}$ of galphimine per dose).

Treatment capsules were identical in appearance. Results revealed a significant effect for Time in favour of both treatments with no significant difference between groups. Galphimia was found to reduce HAMA-rated anxiety by $61.2 \%$ compared with $60.29 \%$ for lorazepam. No significant adverse effects were noted in the galphimia group, whereas $21.33 \%$ of people in the lorazepam group experienced excessive sedation. In a follow-up study by the same group, (51) 191 patients with a DSM-IV diagnosis of GAD and $\geq 20$ on the HAMA were administered two to four capsules (on physician discretion) containing $3.48 \mathrm{~g}$ of dried galphimia per capsule (350 or $700 \mathrm{mg} /$ day of galphimine b), versus 1-2 $\mathrm{mg}$ of lorazepam over a 15-week period. A significantly greater reduction in HAMA score was reported for galphimia treatment in comparison with lorazepam over the course of the study. Tolerability analysis also demonstrated no difference between treatments.

\subsection{Gotu Kola (Centella asiatica)}

Gotu kola has been used in traditional Ayurvedic and Chinese medicine for centuries to treat a range of conditions including anxiety, and to provide relaxation to assist meditation $(52,53)$. The anxiolytic action of gotu kola has been supported in animal studies. In vitro and in vivo research has found the triterpene asiaticoside to be the main active constituent responsible for the anxiolytic activity $(53,54)$. Research in rats has linked triterpenes in gotu kola to increased brain levels of serotonin, noradrenaline and dopamine together with reduced serum corticosterone levels (54).

One study used an animal behavioural model to investigate the anxiolytic activity of various gotu kola extracts administered p.o. to rats (53). They found two gotu kola extracts (high and low asiaticoside) at an acute dose of $500 \mathrm{mg} / \mathrm{kg}$ to significantly reduce anxious behaviour compared with placebo on a number of measures including the EPM. In one human study, Bradwejn and colleagues (55) conducted an acute double-bind RCT investigating gotu kola's anxiolytic activity in 40 healthy participants. Two groups received either placebo or gotu kola at an acute dose of $12 \mathrm{~g}$. Gotu kola was found to significantly reduce the amplitude of the startle response both 30 and 60 min following treatment compared with placebo. A recent 8-week open-label study used gotu kola hydro-ethanolic extract of the leaves (500 mg twice daily) in 33 adults with GAD (56). Results revealed that gotu kola significantly reduced anxiety by $26 \%$ at study endpoint in addition to a reduction in stress and depression ratings. Although the results 
are encouraging, the use of an unvalidated assessment scale, and inadequate reporting restrict confidence in the results.

\subsection{Ginkgo (Ginkgo biloba)}

The ginkgo tree is native to Asia, and the standardized extract of ginkgo leaf has been extensively studied in Europe for use in cognition and dementia, with terpenes and flavonoids being considered the active constituents. Chronic oral treatment of rats with Ginkgo biloba EGb 761 (100 $\mathrm{mg} / \mathrm{kg}$ per day) has shown dose-dependent increases in frontocortical dopamine levels after 14 days (57), while other in vivo research has revealed chronic (14-day) administration to inhibit the reuptake of noradrenaline (58). The anxiolytic effects of ginkgo extract and its four terpenoid components (ginkgolide- $A$, ginkgolide- $B$, ginkgolide- $C$ and bilobalide) were assessed in a study using the EPM in mice (59). When the whole extract $(0.063-1 \mathrm{~g} / \mathrm{kg}$, p.o.) was administered daily for 7 days, the time spent in the open arms of the EPM was prolonged $(0.125 \mathrm{~g} / \mathrm{kg}$ peak effect). Flumazenil administered prior blocked the effect of diazepam, but not ginkgo, indicating an effect not modulated by GABA. Daily administration of ginkgolide-A (1 or $2 \mathrm{mg} / \mathrm{kg}$ ) resulted in an anxiolysis, while no effect occurred for isolated ginkgolide- $B$, ginkgolide- $C$ or bilobalide.

The only human study located was a 4-week RCT using Ginkgo biloba EGb 761 extract (480 or $240 \mathrm{mg}$ daily) versus matching placebo in 107 adults with diagnosed GAD, or adjustment disorder with anxious mood. A significant dose-dependent reduction on the HAMA was found for both active treatment groups in comparison with placebo (60). The HAMA total scores decreased significantly in both the high-dose (480 mg/day), and the low-dose (240 mg/day; though less so) groups in comparison with the placebo group. Effects sizes for GAD were large in both the $480 \mathrm{mg} /$ day group $(d=1.14)$, and the $240 \mathrm{mg} /$ day group $(d=0.76)$. Although increased idiosyncratic bleeding time has been documented in rare case studies, ginkgo has an acceptable safety profile (61).

\subsection{Kava (Piper methysticum)}

The South Pacific plant kava has traditional use for cultural, social and religious occasions. It has also being employed as a medicine, and has been used in Western society for its beneficial effects on reducing anxiety (62). Kava use in Western countries has been popularised since the 1990s, with dozens of kava products (of varying quality) being sold for anxiety and sleep disorders. The pharmacodynamic mechanism for kava's anxiolytic action is thought to be due to the lipophilic resinous constituents known as kavalactones (62). Collectively, kavalactones are concentrated mainly within the rhizomes, roots and root stems of the plant $(63,64)$. The aerial parts of the plant 
may contain toxic alkaloids such as pipermethystine, and are not used in traditional consumption (65). There have been 18 different kavalactones identified to date, with approximately $96 \%$ of the total pharmacological activity being attributed to the presence of six kavalactones: kavain, dihydrokavain, methysticin, dihydromethysticin, demethoxyyangonin and yangonin $(64,66)$.

Numerous preclinical studies suggest possible mechanisms that may mediate the actions of kava extract and specific kavalactones (67) including the following: blockade of voltage-gated sodium ion channels $(68,69)$, reduced excitatory neurotransmitter release due to blockade of calcium ion channels $(70,71)$, enhanced ligand binding to $\mathrm{GABA}_{\mathrm{A}}$ receptors $(72)$, reversible inhibition of monoamine oxidase (MAO) B (73), inhibition of cyclooxygenase (74), and reduced neuronal reuptake of dopamine (75) and noradrenaline (76). An animal study found that kava extract LI 150 (120 or $240 \mathrm{mg} / \mathrm{kg}$, p.o.) induced an anxiolytic-like behaviour similar to diazepam in rats exposed to the EPM, with both interventions significantly increasing entry into the open arms of the maze (77).

A Cochrane meta-analysis of seven RCTs using kava in anxiety (78) revealed a statistically significant mean reduction of 3.85 points on the HAMA over placebo. A recent pooled analysis of kava studies in English (79), including a newly published positive study (Kava Anxiety Depression Spectrum Study) (80), revealed a similar conclusion, with a positive result occurring in four out of six studies reviewed (mean pooled Cohen's $d=1.10$ ). The Kava Anxiety Depression Spectrum Study (KADSS) was a 3-week double-blind, crossover RCT involving 60 adult participants with 1 month or more of elevated generalized anxiety (80). The results revealed that the aqueous extract of kava (Mediherb extract standardized to $250 \mathrm{mg}$ of kavalactones daily) significantly reduced participants' anxiety on the HAMA with a very large clinical effect. The extract was found to be safe and well tolerated, with no serious adverse effects, and no clinical liver toxicity. One study examining the acute use of kava extract (180 mg of kavalactones) in 22 kava-naive adults with mild to moderate anxiety found no significant anxiolytic effect for kava compared with placebo. In contrast, the positive comparator oxazepam did provide a significant reduction of the STAI-State anxiety score (81). This suggests that a medicinal dose of kava in first-time users is not effective.

Kava was withdrawn from European and UK markets in 2002 due to concerns over reported hepatotoxicity (82). Research has been conducted over recent years to determine the pathogenesis, and the present understanding of factors potentially responsible for hepatotoxicity include incorrect cultivar (tudie or wichmanni varieties) being used, an individual's hepatic insufficiency to metabolise kavalactones (cytochrome P450 (CYP) 3A4, 2D6), preparations using acetonic or ethanolic media low in glutathione, potentially contaminated or poorly stored material, and use of aerial parts or root peelings that are higher in alkaloids (83). Therefore, use of only the peeled roots from noble cultivars (traditionally safe and therapeutic cultivated species) using a water solute extraction method is advised (82). 


\subsection{Lemon Balm (Melissa officinalis)}

Lemon balm is indigenous to southern Europe and the Mediterranean, with the leaves being used to improve cognition and mood, and reduce anxiety and stress. Active constituents identified in lemon balm include polyphenolics, flavonoids and triterpenes (84). In vitro and in vivo research has demonstrated various lemon balm extracts to inhibit GABA-transaminase activity, with a methanol extract demonstrating the largest amount of dose-dependent inhibition (85). Of the known active constituents rosmarinic acid, ursolic acid and oleanolic acid have been shown to inhibit GABA-transaminase activity (86). Although rosmarinic acid demonstrates anxiolytic effects at a low dose, high doses have had neurotoxic effects in mice (86). Moreover, ursolic acid was shown to have a moderate affinity for the $\mathrm{GABA}_{\mathrm{A}}$ benzodiazepine receptor site (86). In mice, lemon balm extract has been demonstrated to reduce corticosterone levels in serum (87) as well as the brain (88). Lemon balm has also been shown to increase GABA levels (87) and inhibit MAO in mice (89).

One animal behavioural model investigated the effects of 15 consecutive days of treatment of lemon balm extract (120, 240, and $360 \mathrm{mg} / \mathrm{kg}$, p.o.) standardized for rosmarinic acid, ursolic acid and oleanolic acid on anxiety behaviours in mice (88). The two higher extract doses (but not the $120 \mathrm{mg} / \mathrm{kg}$ ) were found to significantly increase the time spent in the open arms of the EPM, with an effect comparable to benzodiazepines. However, the same extract did not demonstrate a reduction in anxiety in the open field test, which involves more stress than the EPM (88). The authors suggest lemon balm may not be as effective in reducing anxiety if there are high plasma and brain levels of corticosterone.

One prospective open-label pilot study explored the anxiolytic effects of a commercially available preparation of lemon balm in adult outpatients $(n=20)$ with a DSM diagnosis of anxiety disorder and sleep disturbance (84). All participants received lemon balm leaf extract standardized to at least $7 \%$ rosmarinic acid and $15 \%$ hydroxycinnamic acid at a dose of 300 mg twice daily for 15 days. A significant reduction in anxiety manifestations (18\% decline) and associated symptoms ( $15 \%$ decline) from baseline was demonstrated as measured by the Free Rating Scale for Anxiety. Insomnia was also reduced significantly by $42 \%$. Although this study cannot establish efficacy greater than a placebo response, there was a clinically meaningful reduction in anxiety that warrants further investigation. Another two studies showed acute doses of lemon balm to significantly increase self-rated calmness (a secondary measure) compared with placebo following a cognitive battery (90), and a series of stress tests (91). 


\subsection{Milk Thistle (Silybum marianum)}

Milk thistle is a traditional Mediterranean and Persian plant used for a range of psychiatric disorders. A recent RCT using silymarin-rich milk thistle was conducted in Iran (92). Thirty-five participants with a DSM-IV-TR diagnosis of OCD and a score of $>21$ on the Y-BOCS were randomly assigned $200 \mathrm{mg}$ of milk thistle leaf extract (standardisation and chemical profile not disclosed) or $10 \mathrm{mg}$ of fluoxetine three times daily for 8 weeks. Results revealed no significant effect between treatments from baseline to endpoint. It should be noted that the baseline $Y$ BOCS score was very high (41 points), thus in this non-controlled study some statistically significant reduction was probable. Both groups still had a Y-BOCS score of 17 at completion for fluoxetine and 20 for milk thistle (specific data not detailed). The putative anti-OCD effects of milk thistle may be attributable to the flavanoid complex silymarin (containing silibinin, a key constituent), which in preclinical studies has been found to increase serotonin levels in the cortex (93), and ameliorate decreases in dopamine and serotonin in the prefrontal cortex and hippocampus associated with methamphetamine abuse (94). The increase in cortical serotonin levels, and resultant anti-obsessional effects, may be attributable to silibinin's inhibition of MAO activity as revealed by in vitro research (95).

\subsection{Passionflower (Passiflora incarnata)}

The aerial parts of passionflower have a long history of traditional use in the Americas for sleep and anxiety disorders $(96,97)$. There are a number of Passiflora species used traditionally; however, the majority of research has focused on Passiflora incarnata as it has a thorough history of traditional use, and has demonstrated the strongest anxiolytic effect compared with other species (98). The leaves have been identified as the plant part with the greatest anxiolytic action (97). A number of bioactive constituents have been identified, which include amino acids (99), various -carboline alkaloids and flavonoids such as chrysin (36, 39, 100, 101). Chrysin has been identified as a benzodiazepine receptor ligand $(38,102,103)$; however, it appears to have a low receptor binding affinity, and it is suggested that mechanisms other than effects at the $\mathrm{GABA}_{\mathrm{A}}$ receptor may explain the anxiolytic activity $(39,101)$. A benzoflavone compound (BZF) is considered one of the main active constituents responsible for the anxiolytic effect of passionflower (100), although this has been contested (104). Since discovering BZF, studies have standardized passionflower extract for this compound, although the amount standardized for is inconsistent (105-107). One in vitro study has shown passionflower whole leaf extract to preferentially inhibit GABA-transaminase (36). Although in contrast, another study demonstrated the whole plant extract of passionflower to inhibit the uptake of [3-H]-GABA into 
rat cortical synaptosomes, with no effect on GABA-transaminase, GABA release or the benzodiazapine receptor (108).

To date there are 14 studies using standard animal behavioural models to measure the anxiolytic effect of whole plant extracts passionflower $(97,98,100,102,104,105,109-116)$. All of these studies demonstrated anxiolytic effects (usually between 50 and $400 \mathrm{mg} / \mathrm{kg}$ ), although various preparations were used and activity seen a different doses, with sedative effects reported at higher doses $(114,116)$.

Three clinical trials have specifically explored the anxiolytic effects of passionflower, all of which demonstrated significant reductions in anxiety symptoms $(107,117,118)$. One of these studies was a double-bind RCT, investigating outpatients with a DSM diagnosis of GAD $(n=36)$ (96). There were two comparison groups: passionflower extract at 45 drops daily plus placebo tablet, and placebo drops plus oxazepam at $30 \mathrm{mg}$ per day. Both groups demonstrated a statistically significant reduction in total mean HAMA scores at the end of 4 weeks of treatment, with no significant difference between groups. There was a difference in treatment response time between the groups of 3 days, with the passionflower group taking longer ( 7 days) to demonstrate a significant reduction in HAMA scores from baseline compared with the oxazepam group (4 days). While there was no significant difference in frequency of adverse effects, there was an increase in impairment of job performance in the oxazepam group. Two RCTs demonstrated two different preparations of passionflower to significantly reduce acute anxiety compared with placebo in preoperative patients $(107,118)$.

\subsection{Roseroot (Rhodiola rosea)}

Rhodiola rosea has been used therapeutically in parts of the Arctic region and Asia for centuries. Traditionally, it has been ingested as a tea, with the root being used for its therapeutic effects. Roseroot is classed as an adaptogen (a substance that increases the ability of an organism to adapt to environmental demands) (119), and has traditionally been used to reduce stress-related symptoms including irritability, cognitive dysfunction and fatigue (120). It is also widely used in Russia for the treatment of various mental health conditions. The mechanism of action for the anxiolytic effects appears to occur via regulation of the hypothalamic-pituitary-adrenal axis by regulating the stress response through inhibition of cortisol secretion, nitric oxide, mediation of kinase enzymes and modulation of monoamines(120).

A number of bioactive compounds have been identified in roseroot including phenolics, organic acids, flavonoids and tannins. The main active constituents are regarded as the pheylpropane 
compounds collectively known as rosavins, and phenylethane derivatives such as salidroside (120). Preparations are usually standardized for salidrosides and rosavins. Salidroside, rosavin and phenolics are thought to be responsible for the CNS effects and adaptogenic action.

One study to date has explored the effect of an acute oral dose of roseroot hydroalcohol extract $(10,15$ and $20 \mathrm{mg} / \mathrm{kg}$ ) standardized to $3 \%$ rosavins and $1 \%$ salidroside on anxiety-related behaviour in mice (121). Roseroot significantly reduced anxiety-related behaviour in mice compared with placebo on both the light/dark exploration test, and the open-field test, at doses of $10 \mathrm{mg} / \mathrm{kg}$ and $15 \mathrm{mg} / \mathrm{kg}$, respectively.

Although there have been numerous clinical trials demonstrating the efficacy of roseroot as an adaptogen, there has only been one clinical trial specifically investigating the anxiolytic effect of standardized SHR-5 roseroot tablets (122). This was a pilot 10-week, open-label design involving ten participants with a GAD diagnosis and a HAMA score $>17$. Results showed that mean HAMA scores were significantly different at end of treatment compared with baseline. There was also a significant reduction in mean anxiety subscale scores of the Four Dimensional Anxiety and Depression Scale compared with baseline, and five out of ten participants were regarded as responders. As this study was uncontrolled, conclusions as to the compound's efficacy need to be tempered.

\subsection{Sage (Salvia spp.)}

The Salvia genus includes over 900 plants from several regions of the world, and has a long history of use in various systems of traditional medicine due to wide-ranging pharmacological properties including antioxidant, antibacterial and anti-inflammatory effects. Amongst the many constituents of the Salvia genus, the terpenoids (including a-pinene, b-pinene, 1,8-cineole, thujone, camphor and geraniol) are regarded as the main active constituents affecting the CNS, acting as potent acetylcholinesterase and butrylcholinesterase inhibitors $(123,124)$.

Although there are a large number of plants within the Salvia species, only a relatively small number of specific plants have been evaluated for anxiolytic effects using modern scientific methods. Salvia elegans, a herb traditionally used in Mexican medicine, was investigated by Herrera-Ruiz et al. (125). An orally administered hydroalcoholic extract of the leaves and flowers of Salvia elegans were found to exhibit anxiolytic effects at doses of 125, 250 and 2000 $\mathrm{mg} / \mathrm{kg}$ in the EPM and light-dark animal mice models. Similarly, two types of sage that are native to Iran, Salvia leriifolia and Salvia reuterana, have been found to display anxiolytic properties in preclinical research, using the $\operatorname{EPM}(44,126,127)$. 
In relation to clinical studies in humans, there has not been research to date that has examined the effects of sage in a clinical population. However, a study by Kennedy et al. (128) provided initial evidence of acute anxiolytic properties associated with Salvia officinialis in a healthy population. In an acute, double-blind, crossover RCT, 300 versus $600 \mathrm{mg}$ of dried Salvia officinalis leaf was administered to 30 healthy volunteers. The $300 \mathrm{mg}$ dose of sage was found to significantly reduce anxiety, as measured by the STAI-State. However, after 20 min using a multi-tasking battery (designed to elicit stress-related physiological responses) the reduced anxiety effect was abolished (128). It is also noteworthy, that in other studies involving healthy volunteers conducted by this group, both Salvia officinalis as well as Salvia lavandulaefolia (Spanish sage) have been found to reliably induce acute positive mood effects, for example self-rated 'calmness' $(124,129)$. Additional research using clinical samples is warranted in order to further investigate the therapeutic potential of the Salvia genus.

\subsection{Skullcap (Scutellaria lateriflora)}

The aerial parts of skullcap have been used in European and North American traditional medicine $(130,131)$ for anticonvulsant, relaxant and nervous system tonic effects (132). Research has identified diterpenoids, amino acids (GABA and glutamine), essential oil and phenolic compounds in skullcap $(132,133)$. A total of 73 bioactive constituents have been identified in the volatile oil, which include mainly sesquiterpenes (134). Flavones appear to be the main constituents with anxiolytic actions, which include baicalein, baicalin, chrysin and wogonin $(131,133)$. In vitro research has identified baicalein as a weak benzodiazepine receptor ligand, and has demonstrated anxiolytic and sedative effects that appear to be mediated by $\mathrm{GABA}_{A}$ non-benzodiazepine sites (135). In addition, baicalin has demonstrated selective partial $\mathrm{GABA}_{A}$ receptor antagonism (135), and wogonin has shown anxiolytic effects via interaction with benzodiazapine receptors in the GABA system (136). Other flavone glycosides exhibited binding to a $5-\mathrm{HT}_{7}$ receptor (132).

One in vitro study used a whole plant ethanol extract of skullcap, and found the extract inhibited both glutamic acid decarboxylase and GABA-transaminase, with preferential inhibition of GABA-transaminase that appears to contribute to the anxiolytic activity (36). Awad et al. (99) studied an acute oral dose of $100 \mathrm{mg}$ of skullcap aqueous extract to rats in the EPM. Results revealed that treated rats spent significantly more time in the open arms compared with placebo, and displayed significantly less risk assessment behaviour in the open field test. 
One double-bind crossover RCT that investigated the acute anxiolytic effects of skullcap in 19 healthy adults was found (137). Three different extracts of skullcap (100mg, 200mg and $350 \mathrm{mg}$ ) were compared with placebo with a minimum of 2 days separating treatments. Selfassessments of anxiety levels were provided at baseline, 30-, 60-, 90- and 120-min post-dose using an 11-point Likert scale. All three skullcap preparations demonstrated anxiolytic effects on the Acute Psycho-Activity Self-Rating Scale. Although a clinical effect was seen, no statistical data were reported and there were numerous methodological flaws making it impossible to draw conclusions on the anxiolytic effects of skullcap based on this study.

\subsection{St John's Wort (Hypericum perforatum)}

St John's wort (SJW) has been therapeutically used throughout Europe and studied extensively in depression $(4,138)$. SJW has revealed equivalent efficacy to conventional antidepressants due to a range of neurobiological effects in both animal and in vitro models, including reuptake inhibition of monoamines, increased sensitisation and binding to receptors (e.g. serotonin), and neuroendocrine modulation. These effects were attributed to a number of bioactive constituents including hyperforin, hypericin and pseduohypericin $(139,140)$.

No study has been conducted on the efficacy of SJW in 'generalized anxiety' or GAD to date. However, SJW has been assessed in OCD and SP. A standardized SJW extract was assessed in an open-label pilot trial for efficacy in OCD (141). Twelve subjects with a chronic (>12 months) DSM-IV diagnosis of OCD were treated for 12 weeks with $450 \mathrm{mg}$ of standardized SJW $(0.3 \%$ hypericin) twice daily. A significant change on the Y-BOCS from baseline to study endpoint was found. This change occurred at week 1 and continued until week 12. At the study endpoint, five (42\%) of 12 participants were rated as being 'much' or 'very much improved' on clinician-rated improvement; six (50\%) were 'minimally improved', and one (8\%) had 'no change'. A later RCT by the same research group (142) using SJW (LI 160) was performed to confirm these results. Sixty participants with a primary diagnosis of OCD of at least 12 months duration were randomized to either 12 weeks of SJW treatment (flexible dosing 600-1800 mg depending on response) or matching placebo. Results revealed that the mean reduction on the Y-BOCS in the SJW group did not significantly differ from placebo. No significant differences were found on any of the Y-BOCS subscales. A 12-week double-blind RCT testing SJW (flexible dose of 600-1800 $\mathrm{mg}$ daily) in 40 participants with SP reported no significant differential benefit over placebo on the Liebowitz Social Anxiety Scale (143).

\subsection{Valerian (Valeriana spp.)}


The Valeriana spp. comprises over 200 species worldwide, with extracts from the roots having a long history of traditional use across Europe and the Americas as a sedative (144). The sesquiterpenoids (valerenic acid) and valepotriates are the main active constituents of valerian (145). Valerian extract, in particular valerenic acid, has been found to activate adenosine receptors and potentiate synaptic GABAergic transmission via $\mathrm{GABA}_{\mathrm{A}}$ receptors $(146,147)$. In vivo, valerenic acid has demonstrated strong anxiolytic activity in mice, using both the EPM and the light/dark choice test at $10 \mathrm{mg} / \mathrm{kg}$ p.o. and $3 \mathrm{mg} / \mathrm{kg}$ p.o.(147). There is also evidence to suggest that valepotriates potentiate GABAergic transmission (148). Oral valerian $(12 \mathrm{mg} / \mathrm{kg}) \mathrm{has}$ increased the time spent by rats in the open arms of the EPM during withdrawal of diazepam (after 28 days of administration) (149).

A 2006 Cochrane review of valerian for anxiety disorders conducted by Miyasaka et al. (150) revealed only one chronic RCT met inclusion criteria, involving 36 patients with a DSM-III-R diagnosis of GAD. In a three-arm, double-blind, parallel-group design, Andreatini et al. (151) administered valepotriates at a mean daily dose of $81.3 \mathrm{mg}$ versus diazepam at a mean daily dose of $6.5 \mathrm{mg}$ or placebo, over a 4-week period. No significant differences between valerian and placebo were found post-treatment on either the HAMA or the STAI-Trait scores. Comparing valerian to diazepam, no significant differences were found for the HAMA, although the STAITrait score was significantly lower in the diazepam group in comparison with valerian posttreatment. It is important to note that the sample size was small, and only isolated valepotriates were used in this study. Comparisons to commercially available whole galenic extracts are therefore difficult to make. Further, due to safety concerns regarding the cytotoxic potential of valepotriates in valerian extracts $(152,153)$, commercially available extracts are generally higher in valerenic acid in comparison with valepotriates (144).

In addition to the single study identified in the Cochrane review, an open-label study in healthy volunteers was identified (154). Valerian was administered to 33 subjects at a dose of $500 \mathrm{mg}$ twice daily for 60 days. Significant reductions in anxiety as measured by the Brief Psychiatric Rating Scale (BPRS) were reported at day 60, although without the inclusion of a placebo group it is difficult to draw firm conclusions as to the anxiolytic efficacy of valerian from this small study.

\section{Psychotropic Plant-Based Treatments with Potential Use in Anxiety Disorders}




\subsection{Psilocybe (Psilocybe spp.)}

A number of wild species of mushrooms (e.g., Psilocybe cyanescens and Psiolocybe subaeuruginosa) have been used globally for millennia in traditional medicine for spiritual applications, such as in shamanic rituals. Psilocybe mushrooms contain the psychoactive compound psilocybin (4-phosphoryloxy- dimethyltryptamine (DMT)), which is a classical hallucinogen of the indoleamine class. When ingested p.o., psilocybin is converted into the active compound psilocin through the action of phosphatases. A dose-escalation study by Griffiths et al. (155) indicated that acute perceptual and subjective effects are reliably induced using doses of $20-30 \mathrm{mg} / 70 \mathrm{~kg}(285-428 \mu \mathrm{g} / \mathrm{kg}$, p.o.). In comparison to the well known hallucinogen lysergic acid diethylamide (LSD), the hallucinogenic experience associated with psilocybin has been reported to be more euphoric and less emotionally intense, as well as being associated with less panic reactions and paranoia (156). A recent pooled analysis of eight clinical studies, with a total sample size of 110 participants, reported that moderate doses of psilocybin ( $<250 \mu \mathrm{g} / \mathrm{kg}$ ) were not found to be associated with clinically significant adverse psychological effects. However, adverse reactions including strong dysphoria and/or anxiety/panic were reported in a small proportion of participants when administered high doses of psilocybin; $7.3 \%$ of participants at $315 \mu \mathrm{g} / \mathrm{kg}$, and $5.7 \%$ of participants at $250-260 \mu \mathrm{g} / \mathrm{kg}$. All acute adverse reactions were successfully managed with interpersonal support and did not require pharmacological intervention (157).

The use of psilocybe mushrooms or the isolated psilocybin component may provide a novel intervention for anxiety disorders. Current evidence indicates that the psychotropic effects of psilocybin may be attributable to agonist action at post-synaptic $5-\mathrm{HT}_{2 \mathrm{~A}}$ receptors that results in potent modulation of activity in prefrontal networks $(158,159)$. Due to the fact that fronto-limbic $5-\mathrm{HT}_{2 \mathrm{~A}}$ receptor density has been found to be elevated in individuals with anxiety and difficulty coping with stress (160), a possible mechanism by which psilocybin may exert therapeutic effects is through down-regulation of prefrontal $5-\mathrm{HT}_{2 \mathrm{~A}}$ receptors (161).

Following on from early reports that psychedelics may help to reduce anxiety and improve quality of life in the terminally ill (162), Grob et al. (163) recently conducted an investigation into the efficacy of psilocybin for the treatment of anxiety in advanced-stage cancer patients. In this double-blind, placebo-controlled, crossover trial, $200 \mu \mathrm{g} / \mathrm{kg}$ of psilocybin or $250 \mathrm{mg}$ of niacin was administered p.o. to 12 advanced-stage cancer patients across two experimental treatment sessions spaced several weeks apart. The patients were monitored over a 6-h period corresponding to the duration of the acute hallucinogenic effects, and then monitored again 2 weeks later and at monthly follow-up visits for up to 6 months. During the acute phase of 
treatment, a significant alteration of consciousness was found to be associated with psilocybin in comparison with placebo, as measured using the 5-Dimension Altered States of

Consciousness profile; effects included a significant elevation of positive mood. A trend towards a greater reduction in the Profile of Mood States score in the psilocybin group in comparison with placebo was observed from baseline to week 2 . In the longer term follow-up, the STAI-Trait anxiety score was significantly reduced at both 1 and 3 months post-treatment, together with a significant improvement in mood using the Beck Depression Inventory at 6 months. The treatment was well tolerated and no significant adverse psychological effects were found to be associated with psilocybin. However, these findings need to be interpreted with caution in consideration of the fact that from 1 month onwards the patients had received both psilocybin and placebo treatments at some stage. The authors acknowledge this limitation, but explain that the study design employed was the only ethical course of treatment in consideration of the grave prognosis in the patient group (163). Notwithstanding this caveat, this trial provides intriguing preliminary data in support of psilocybin as an effective treatment for the amelioration of anxiety in the critically ill.

Psilocybin has also been investigated for its efficacy in the treatment of OCD. Early anecdotal reports suggested that the use of hallucinogens may be associated with acute amelioration of OCD symptoms (164). In one such case report, a 34-year-old man who had suffered from OCD since adolescence reported that the repeated use of psilocybe mushrooms consistently led to freedom from obsessions and compulsions during the period of intoxication and eventually led to a remission that lasted several months (165). However, it has not been until recently that a clinical study has been conducted in this area. Moreno et al. (166) conducted an open-label psilocybin dose-escalation study in nine patients with a DSM-IV diagnosis of OCD with at least one treatment failure related to the use of selective serotonin reuptake inhibitors (SSRIs). Patients were required to complete a 2-week washout period for antidepressants prior to the study, and then were required to attend four separate study visits separated by at least 1 week. At each visit they received one of four doses of psilocybin $(25,100,200$ and $300 \mu \mathrm{g} / \mathrm{kg}$ ) and were monitored for the next $8 \mathrm{~h}$ in a controlled environment before being transferred to a psychiatric inpatient unit overnight. All dosages of psilocybin were well tolerated, and $88.9 \%$ of patients maintained $\mathrm{a} \geq 25 \%$ decrease in the Y-BOCS score at $24 \mathrm{~h}$ for at least one of the doses. In addition, $66.7 \%$ of patients maintained a $\geq 50 \%$ decrease in the $\mathrm{Y}$-BOCS score at 24$\mathrm{h}$ post-treatment for at least one of the doses. Although OCD measurements did not extend past $24 \mathrm{~h}$, two of the patients reported that symptom relief lasted for most of the following week after testing. Interestingly, no significant differences in symptomatology were reported between the dosage levels. The authors acknowledge that the lowest dose $(25 \mu \mathrm{g} / \mathrm{kg})$ was intended as a placebo comparator, although the study outcomes indicate that even at this level there was a 
treatment effect; this methodological issue limits the interpretation of the findings. However, despite the limitations this study provides important preliminary evidence as to possible acute reduction in OCD symptoms associated with psilocybin treatment (166). These findings also corroborate a previous preclinical study in mice by Matsushima et al. (167) who reported that the administration of Psilocybe argentipes, a variety of psychedelic mushroom containing psilocybin, resulted in a significant reduction in marble-burying activity, a commonly used animal model of OCD.

\subsection{Ayahuasca (Psychotria viridis and Banisteriopsis caapi)}

Ayahuasca is a traditional South American beverage that is prepared by boiling the bark and stems of the jungle vine Banisteriopsis caapi together with the Rubiaceous genus Psychotria. Ayahuasca has a long history of use amongst indigenous tribes of the Amazon Basin where it has been used both for religious ceremonies and for the diagnosis and treatment of physiological and psychological ailments (168). In an unprecedented move by the Brazilian government in 1987, ayahuasca was approved for use in the context of religious ceremonies. The active constituent of ayahuasca is the potent indoleamine class hallucinogen N, N-DMT. However, DMT is not orally active by itself, and for this reason must be combined with $\beta$ carboline alkaloids found in Banisteriopsis caapi bark, which act as MAO-A inhibitors to prevent the oxidative deamination of DMT (169). The psychotropic effects of ayahuasca, together with indoleamine hallucinogens in general, are understood to be attributable to agonist action at post-synaptic $5-\mathrm{HT}_{2 \mathrm{~A}}$ receptors (158).

In a study of the acute pharmacology of ayahuasca, Riba et al. (170) administered 0.6 and 0.85 $\mathrm{mg} / \mathrm{kg}$ of DMT versus placebo to 18 healthy volunteers in a double-blind design. Acute subjective effects were captured at several post-dose time points up until $8 \mathrm{~h}$ using visual analogue scales (VAS), the Hallucinogen Rating scale and the Addiction Research Center Inventory. Ayahuasca at both doses was found to be associated with a number of significant subjective changes including increased activation, euphoria, well-being, perceptual modifications, and changes in thought content and increased emotional lability. Peak subjective effects were found to coincide with peak plasma concentrations of DMT between 1.5- and 2-h post-dose, and returned to baseline by 6 -h post-dose. A number of subjective effects were found to be stronger following the higher dose of ayahuasca, yet interestingly the VAS scale for 'drunken' was least affected by ayahuasca at both dosage levels. In consideration of the fact that the VAS drunken scale is generally associated with sedatives and alcohol, this indicates that ayahuasca intoxication is qualitatively different from these substances (170). 
Investigations into the therapeutic potential of ayahuasca have been gaining momentum in recent years. A seminal study in this area, known as the Hoasca Project was conducted by Dennis McKenna and colleagues in the early 1990s $(169,171)$. The participants involved in this study were 15 members of the Uniao do Vegetal (UDV) syncretic sect in Brazil who had ingested ayahuasca an average of once every 2 weeks over a minimum period of 10 years. Using a battery of psychological assessments, the UDV members were compared with 15 ayahuasca-naive age-matched controls. The UDV members were found to perform significantly better than the controls on the WHO-UCLA Auditory Leaning Verbal Memory test and to be of high functional status according to structured interviews. Of particular interest was the finding that a number of UDV members with previous histories of violent behaviour and alcoholism had experienced symptomatic remission since joining the UDV (171). Measurement of platelet serotonin transporter density was also found to be elevated in UDV members in comparison with controls, a finding that the authors suggest may be indicative of serotonin transporter density increases in the CNS and may be a possible factor influencing positive behavioural changes (172).

More recently, Santos et al. (173) conducted a double-blind, placebo-controlled investigation into the acute effects of ayahuasca on measures of anxiety, panic and hopelessness in members of the Santo-Daime ayahuasca-using religion of Brazil. Nine participants were included in the study, all of which had used ayahuasca for at least 10 consecutive years. Measures of state/trait anxiety, panic and hopelessness were assessed $1 \mathrm{~h}$ after ingestion of ayahuasca. Significant differences between placebo and ayahuasca were found on Panicrelated signs as well as Beck Hopelessness, while differences on STAI-Trait and State anxiety scores did not reach significance. Although studies of both the chronic and acute therapeutic efficacy of ayahuasca are still in their infancy, the long history of traditional therapeutic use coupled with encouraging initial data suggests that further investigations in the application for anxiety disorders are warranted.

\subsection{Marijuana (Cannabis sativa/indica)}

Marijuana has been propagated and traded across the globe for centuries. Although it has potential medicinal uses, there is now strong evidence to suggest that the recreational use of marijuana is associated with an increased incidence of mental health problems across a range of disorders including depression, anxiety and psychosis $(174,175)$. However, it is important to differentiate the adverse psychological effects of tetrahydrocannabinol ( $\Delta^{9}$-THC) with those of the lesser-known constituent cannabidiol (CBD). In contrast to $\Delta^{9}-T H C$, CBD has low affinity for endogenous cannabinoid receptors (CB1 and CB2) as well as antagonistic actions at these 
receptors. In addition, there is evidence to suggest that $\mathrm{CBD}$ may act as an agonist at $5-\mathrm{HT}_{1 \mathrm{~A}}$ receptors (176). A number of animal as well as human studies have now provided evidence to suggest that CBD may ameliorate both anxiety and panic responses. Resstel et al. (177) investigated the effect of $\mathrm{CBD}$ on restraint stress in male rats and found that the anxiogenic response in the EPM was attenuated following an intraperitoneal injection of CBD. Interestingly, in a follow-up experiment, Resstel et al. (177) reported that the anxiolytic effects of CBD were blocked using the $5-\mathrm{HT}_{1 \mathrm{~A}}$ antagonist WAY-100635. This indicates an effect meditated in part by the serotonergic pathway. In relation to human trials, CBD has been investigated as a treatment for generalized SP in a double-blind RCT of 24 patients. Through the use of a simulated public speaking test, SP patients who were pretreated with $600 \mathrm{mg}$ of CBD $1 \mathrm{~h}$ before testing were found to display significantly reduced anxiety, cognitive impairment and discomfort in their speech performance in comparison to controls (178). Similar anxiolytic effects of CBD have also been reported when healthy participants were subjected to a simulated public speaking test (179).The research into the CBD component of marijuana is encouraging, raising the possibility that new strains of marijuana may be cultivated with high CBD and low $\Delta^{9}$-THC levels, which may be safer and of greater therapeutic potential.

\section{Conclusions}

In summary, our review of chronic and acute human studies revealed evidence for anxiolytic effects for 21 plants, with evidentiary support from multiple trials for kava and galphimia in reducing generalized anxiety. Isolated positive studies exist for the chronic use (1-8 weeks) of passionflower, gotu kola, chamomile, skullcap, roseroot, ginkgo, ashwagandha, echinacea, Iranian borage, lemon balm and milk thistle. Studies using acute application of plants, revealed isolated positive studies for passionflower, lemon balm, bitter orange, gotu kola and sage. Brahmi has been shown to have anxiolytic effects on surrogate outcomes for people with cognitive decline.

For specific clinical anxiety disorders, there is currently only tentative evidence for milk thistle, Iranian borage and psilocybin in OCD; and ginkgo, chamomile, roseroot, galphimia, gotu kola and ashwagandha for GAD; while SJW appears to not be effective for OCD or SP. An interesting potential application that was uncovered was the use of traditional psychotropic plant-based medicines for treatment of anxiety. Although safety issues need to be observed if researching or consuming these plant medicines, it is an area of novel application that may hold benefit. While clinical research into the therapeutic potential of psilocybin and other hallucinogens flourished during the 1950s and 1960s, a subsequent hiatus on research 
programmes in this area was imposed due to the political backlash following their recreational use and the subsequent scheduling of these substances (180). Regardless, in recent years there has been a renaissance in research regarding their therapeutic effects.

While global research in the area is encouraged, there is currently a challenge in properly establishing the anxiolytic properties of plants in cases where the only data available have been obtained from under-powered and poorly controlled studies. As detailed in this review, many studies are short term (1-4 weeks), some studies are open-label, and in several cases the data were poorly reported. To date only kava has been sufficiently studied for anxiety. All of the other plant medicines need to have replicated studies, or in cases of poor methodology (i.e., skullcap, echinacea, roseroot) future studies need to use a more rigorous trial design and larger samples.

Furthermore, studies on plant medicines sometimes do not use clearly established standardized, chemically defined extracts (e.g., Iranian borage, milk thistle). This deficit of 'bioequivalence' between extracts hampers the advancement of knowledge regarding the anxiolytic properties of botanicals as viable alternatives to pharmaceuticals. This problem could be resolved if appropriate information regarding the exact quantities of active constituents was provided in future clinical study papers. One further challenge is that chemical composition of herbal preparation depends on many factors, such as genetic and environmental differences, exposure to airborne vectors, differences in plant parts used, harvest time and preparation methods. The application of analytic and 'omic' technology would greatly assist in providing assurance of bioequivalence $(181,182)$.

Although anxiolytic plant medicines can be considered to have a favourable adverse effect profile compared with conventional medication for anxiety (e.g. benzodiazepines, antidepressants), safety issues still need to be considered. Mild adverse effects that may infrequently occur from plant medicines include digestive disturbance, headaches and skin reactions. In regard to kava, due to previous cases of liver toxicity, only reputable kava raw material and products should be used, in addition to occasional liver function tests by regular consumers. Interactions with concomitant use of medications may occur if the plant medicine modulates the CYP system or the p-glycoprotein drug pump (such as in the case of hyperforinrich SJW products). In addition, some products from unscrupulous sources have previously been tainted with prescription drugs, and in some cases the reputed plant has been substituted with toxic plants such as germander. To combat this, judicious use of regulation and pharmacovigilance is required. Another safety issue involves the inappropriate use of plant medicines lacking evidence as first-line interventions for severe mental illness. 
In conclusion, while some evidence in this area is encouraging, future research in several cases needs to replicate the positive isolated studies to confidently confirm efficacy.

\section{References}

1. American Psychiatric Association. Diagnostic and statistical manual of mental disorders. 4th text revision ed. Arlington (VA): American Psychiatric Association, 2000.

2. Sarris J, McIntyre E, Camfield D. Plant-based medicines for anxiety disorders, part 1: a review of preclinical studies. CNS Drugs. 2013;27(3):

3. Sarris J. Herbal medicines in the treatment of psychiatric disorders: a systematic review. Phytother Res. 2007;21(8):703-16.

4. Sarris J, Kavanagh DJ. Kava and St John's wort: current evidence for use in mood and anxiety disorders. J Altern Complement Med. 2009;15(8):827-36.

5. Spinella M. The psychopharmacology of herbal medicine: plant drugs that alter mind, brain and behavior. Cambridge: MIT Press, 2001.

6. Awad R, Levac D, Cybulska $P$, et al. Effects of traditionally used anxiolytic botanicals on enzymes of the gamma-aminobutyric acid (GABA) system. Can J Physiol Pharmacol. 2007;85(9):93342.

7. Kumar V. Potential medicinal plants for CNS disorders: an overview. Phytother Res. 2006; 20(12):1023-35.

8. Sarris J, Panossian A, Schweitzer I, et al. Herbal medicine for depression, anxiety and insomnia: a review of psychopharmacology and clinical evidence. Eur Neuropsychopharmacol. 2011;21(12):841-60.

9. Lakhan SE, Vieira KF. Nutritional and herbal supplements for anxiety and anxiety-related disorders: systematic review. Nutrition J. 2010;9:42.

10. Chen HC, Hsieh MT, Lai E. Studies on the suanzaorentang in the treatment of anxiety. Psychopharmacology (Berl). 1985;85(4):486-7.

11. Yuzurihara $M$, Ikarashi $Y$, Ishige $A$, et al. Anxiolytic-like effect of saiboku-to, an oriental herbal medicine, on histaminergics-induced anxiety in mice. Pharmacol Biochem Behav. 2000;67(3):489-95. 12. Kuribara $\mathrm{H}$, Iwata $\mathrm{H}$, Tomioka $\mathrm{H}$, et al. The anxiolytic effect of Sho-ju-sen, a Japanese herbal medicine, assessed by an elevated plus-maze test in mice. Phytother Res. 2001;15(2):142-7.

13. Mantani N, Hisanaga A, Kogure T, et al. Four cases of panic disorder successfully treated with Kampo (Japanese herbal) medicines: Kami-shoyo-san and Hange-koboku-to. Psychiatry Clin Neurosci. 2002;56(6):617-20.

14. Lin YC, Hsieh MT, Chen CF, et al. Anxiolytic effect of ting-chih-wan in mouse behavior models of anxiety. Am J Chinese Med. 2003;31(1):47-59.

15. Mizoguchi K, Ikeda R, Shoji H, et al. Saikokaryukotsuboreito, a herbal medicine, prevents chronic stress-induced anxiety in rats: comparison with diazepam. J Nat Med. 2009;63(1):69-74. 16. Mizoguchi K, Tanaka Y, Tabira T. Anxiolytic effect of a herbal medicine, yokukansan, in aged rats: involvement of serotonergic and dopaminergic transmissions in the prefrontal cortex. J Ethnopharmacol. 2010;127(1):70-6.

17. Wang HN, Peng Y, Tan QR, et al. Free and Easy Wanderer Plus (FEWP), a polyherbal preparation, ameliorates PTSD-like behavior and cognitive impairments in stressed rats. Prog Neuropsychopharmacol Biol Psychiatry. 2009;33(8):1458-63. 
18. Meng XZ, Wu F, Wei PK, et al. A chinese herbal formula to improve general psychological status in posttraumatic stress disorder: a randomized placebo-controlled trial on sichuan earthquake survivors. Evid Based Complement Alternat Med. 2012;2012:691258.

19. Bhattacharya SK, Muruganandam AV. Adaptogenic activity of Withania somnifera: an experimental study using a rat model of chronic stress. Pharmacol Biochem Behav. 2003;75(3):54755.

20. Mehta AK, Binkley P, Gandhi SS, et al. Pharmacological effects of Withania somnifera root extract on GABAA receptor complex. Indian J Med Res. 1991;94:312-5.

21. Bhattacharya SK, Bhattacharya A, Sairam K, et al. Anxiolytic-antidepressant activity of Withania somnifera glycowithanolides: an experimental study. Phytomedicine. 2000;7(6):463-9.

22. Andrade C, Aswath A, Chaturvedi SK, et al. A double-blind, placebo-controlled evaluation of the anxiolytic efficacy of an ethanolic extract of withania somnifera. Indian J Psychiatry. 2000;42(3):295-301.

23. Russo A, Borrelli F. Bacopa monniera, a reputed nootropic plant: an overview. Phytomedicine. 2005;12(4):305-17.

24. Raghav SS, Dalal H, Srivastava PK, et al. Randomized controlled trial of standardized Bacopa monniera extract in age-associated memory impairment. Indian J Psychiatry. 2006;48:238-42.

25. Charles PD, Ambigapathy G, Geraldine P, et al. Bacopa monniera leaf extract up-regulates tryptophan hydroxylase (TPH2) and serotonin transporter (SERT) expression: implications in memory formation. J Ethnopharmacol. 2011;134(1):55-61

26. Singh HK, Dhawan BN. Neuropsychopharmacological effects of the ayurvedic nootropic Bacopa monniera Linn. Indian J Pharmacol. 1997;29(5):S359-S65.

27. Chatterjee $\mathrm{M}$, Verma P, Palit G. Comparative evaluation of Bacopa monniera and Panax quniquefolium in experimental anxiety and depressive models in mice. Indian J Exp Biol. 2010;48(3):306-13.

28. Pase M, Kean J, Sarris J, et al. The cognitive enhancing effects of Bacopa monneiri: a systematic review of randomized, controlled human clinical trials. J Altern Complement Med. 2012;18(7):647-52.

29. Calabrese C, Gregory WL, Leo M, et al. Effects of a standardized Bacopa monnieri extract on cognitive performance, anxiety, and depression in the elderly: a randomized, double-blind, placebocontrolled trial. J Altern Complement Med. 2008;14(6):707-13.

30. Stough C, Lloyd J, Clarke J, et al. The chronic effects of an extract of Bacopa monniera (Brahmi) on cognitive function in healthy human subjects. Psychopharmacology (Berl). 2001;156(4):481-4.

31. Bagetta G, Morrone LA, Rombola L, et al. Neuropharmacology of the essential oil of bergamot. Fitoterapia. 2010;81(6):453-61.

32. Saiyudthong $S$, Marsden CA. Acute effects of bergamot oil on anxiety-related behaviour and corticosterone level in rats. Phytother Res. 2011;25(6):858-62.

33. Akhlaghi $M$, Shabanian $G$, Rafieian-Kopaei $M$, et al. Citrus aurantium blossom and preoperative anxiety. Revista brasileira de anestesiologia. 2011;61(6):702-12.

34. Amsterdam JD, Li Y, Soeller I, et al. A randomized, double-blind, placebo-controlled trial of oral Matricaria recutita (chamomile) extract therapy for generalized anxiety disorder. J Clin Psychopharmacol. 2009;29(4):378-82.

35. Avallone R, Zanoli P, Puia G, et al. Pharmacological profile of apigenin, a flavonoid isolated from Matricaria chamomilla. Biochem Pharmacol. 2000;59(11):1387-94.

36. Awad R, Levac D, Cybulska $P$, et al. Effects of traditionally used anxiolytic botanicals on enzymes of the $\gamma$-aminobutyric acid (GABA) system. Can J Physiol Pharmacol. 2007;85(9):933-42.

37. Viola $\mathrm{H}$, Wasowski $\mathrm{C}$, Levi de Stein $\mathrm{M}$, et al. Apigenin, a component of Matricaria recutita flowers, is a central benzodiazepine receptors-ligand with anxiolytic effects. Planta Med. 1995;61(3):213-6. 
38. Salgueiro JB, Ardenghi P, Dias M, et al. Anxiolytic natural and synthetic flavonoid ligands of the central benzodiazepine receptor have no effect on memory tasks in rats. Pharmacol Biochem Behav. 1997;58(4):887-91.

39. Zanoli P, Avallone R, Baraldi M. Behavioral characterisation of the flavonoids apigenin and chrysin. Fitoterapia. 2000;71 Suppl 1:S117-S23.

40. Haller J, Hohmann J, Freund TF. The effect of Echinacea preparations in three laboratory tests of anxiety: comparison with chlordiazepoxide. Phytother Res. 2010;24(11):1605-13.

41. Haller J, Freund TF, Pelczer KG, et al. The anxiolytic potential and psychotropic side effects of an echinacea preparation in laboratory animals and healthy volunteers. Phytother Res.

2013;27(1):54-61.

42. Gertsch J, Schoop R, Kuenzle U, et al. Echinacea alkylamides modulate TNF-alpha gene expression via cannabinoid receptor CB2 and multiple signal transduction pathways. FEBS Lett. 2004;577(3):563-9.

43. Tambaro S, Bortolato M. Cannabinoid-related agents in the treatment of anxiety disorders: current knowledge and future perspectives. Recent Pat CNS Drug Discov. 2012;7(1):25-40.

44. Rabbani M, Vaseghi G, Sajjadi SE, et al. Persian herbal medicines with anxiolytic properties. J Medicinal Plant. 2011;10(39):7-11.

45. Sayyah M, Boostani $\mathrm{H}$, Pakseresht $\mathrm{S}$, et al. Efficacy of aqueous extract of Echium amoenum in treatment of obsessive-compulsive disorder. Prog Neuropsychopharmacol Biol Psychiatry. 2009;33(8):1513-6.

46. Rabbani M, Sajjadi SE, Vaseghi G, et al. Anxiolytic effects of Echium amoenum on the elevated plus-maze model of anxiety in mice. Fitoterapia. 2004;75(5):457-64.

47. Jimenez-Ferrer E, Herrera-Ruiz $M$, Ramirez-Garcia R, et al. Interaction of the natural anxiolytic galphimine-B with serotonergic drugs on dorsal hippocampus in rats. J Ethnopharmacol. 2011;137(1):724-9.

48. Herrera-Ruiz M, Gonzalez-Cortazar M, Jimenez-Ferrer E, et al. Anxiolytic effect of natural galphimines from Galphimia glauca and their chemical derivatives. J Nat Prod. 2006;69(1):59-61. 49. Herrera-Ruiz M, Jimenez-Ferrer JE, De Lima TC, et al. Anxiolytic and antidepressant-like activity of a standardized extract from Galphimia glauca. Phytomedicine. 2006;13(1-2):23-8. 50. Herrera-Arellano A, Jimenez-Ferrer E, Zamilpa A, et al. Efficacy and tolerability of a standardized herbal product from Galphimia glauca on generalized anxiety disorder: a randomized, double-blind clinical trial controlled with lorazepam. Planta Med. 2007;73(8):713-7.

51. Herrera-Arellano A, Jiménez-Ferrer JE, Zamilpa A, et al. Therapeutic effectiveness of galphimia glauca vs lorazepam in generalized anxiety disorder: a controlled 15-week clinical trial. Planta Medica. 2012;78(14):1529-35.

52. Bradwejn J, Zhou Y, Koszycki D, et al. A double-blind, placebo-controlled study on the effects of gotu kola (Centella asiatica) on acoustic startle response in healthy subjects. J Clin Psychopharmacol. 2000;20(6):680.

53. Wijeweera P, Arnason JT, Koszycki D, et al. Evaluation of anxiolytic properties of Gotu kola (Centella asiatica) extracts and asiaticoside in rat behavioral models. Phytomedicine. 2006;13(910):668-76.

54. Chen Y, Han T, Rui Y, et al. Effects of total triterpenes of Centella asiatica on the corticosterone levels in serum and contents of monoamine in depression rat brain. J Chinese Medicinal Materials (Zhongyaocai). 2005;28(6):492-6.

55. Bradwejn J, Zhou Y, Koszycki D, et al. A double-blind, placebo-controlled study on the effects of gotu kola (Centella asiatica) on acoustic startle response in healthy subjects. J Clin Psychopharmacol. 2000;20(6):680-4.

56. Jana U, Sur TK, Maity LN, et al. A clinical study on the management of generalized anxiety disorder with Centella asiatica. NMCJ. 2010;12(1):8-11. 
57. Yoshitake T, Yoshitake S, Kehr J. The ginkgo biloba extract EGb 761(R) and its main constituent flavonoids and ginkgolides increase extracellular dopamine levels in the rat prefrontal cortex. Br J Pharmacol. 2010;159(3):659-68..

58. Fehske CJ, Leuner K, Muller WE. Ginkgo biloba extract (EGb761) influences monoaminergic neurotransmission via inhibition of NE uptake, but not MAO activity after chronic treatment. Pharmacol Res. 2009;60(1):68-73.

59. Kuribara $\mathrm{H}$, Weintraub ST, Yoshihama $\mathrm{T}$, et al. An anxiolytic-like effect of ginkgo biloba extract and its constituent, ginkgolide-A, in mice. J Nat Prod. 2003;66(10):1333-7.

60. Woelk H, Arnoldt KH, Kieser M, et al. Ginkgo biloba special extract EGb 761((R)) in generalized anxiety disorder and adjustment disorder with anxious mood: a randomized, doubleblind, placebo-controlled trial. J Psychiatr Res. 2007;41(6):472-80.

61. Koch E. Inhibition of platelet activating factor (PAF)-induced aggregation of human thrombocytes by ginkgolides: considerations on possible bleeding complications after oral intake of ginkgo biloba extracts. Phytomedicine. 2005;12(1-2):10-6.

62. Bilia AR, Gallon S, Vincieri FF. Kava-kava and anxiety: growing knowledge about the efficacy and safety. Life Sci. 2002;70(22):2581-97.

63. Raduege KM, Kleshinski JF, Ryckman JV, et al. Anesthetic considerations of the herbal, kava. J Clin Anesth. 2004;16(4):305-11.

64. Singh YN, Singh NN. Therapeutic potential of kava in the treatment of anxiety disorders. CNS Drugs. 2002;16(11):731-43.

65. Nerurkar PV, Dragull K, Tang CS. In vitro toxicity of kava alkaloid, pipermethystine, in HepG2 cells compared to kavalactones. Toxicol Sci. 2004;79(1):106-11.

66. Lebot $\mathrm{V}$, Lévesque J. The origin and distribution of kava (Piper methysticum Forst. f. and Piper wichmannii C. DC., Piperaceae): a phytochemical approach. Allertonia 1989;5:223-80.

67. Sarris J, LaPorte E, Schweitzer I. Kava: a comprehensive review of efficacy, safety, and psychopharmacology. Aust N Z J Psychiatry. 2011;45(1):27-35.

68. Magura El, Kopanitsa MV, Gleitz J, et al. Kava extract ingredients, (+)-methysticin and (+/-)kavain inhibit voltage-operated $\mathrm{Na}(+)$-channels in rat CA1 hippocampal neurons. Neuroscience. 1997;81(2):345-51.

69. Gleitz J, Beile A, Peters T. (+/-)-Kavain inhibits veratridine-activated voltage-dependent $\mathrm{Na}(+)$-channels in synaptosomes prepared from rat cerebral cortex. Neuropharmacology. 1995;34(9):1133-8.

70. Martin HB, McCallum M, Stofer WD, et al. Kavain attenuates vascular contractility through inhibition of calcium channels. Planta Med. 2002;68(9):784-9.

71. Walden J, von Wegerer J, Winter U, et al. Effects of kawain and dihydromethysticin on field potential changes in the hippocampus. Prog Neuropsychopharmacol Biol Psychiatry. 1997;21(4):697706.

72. Jussofie A, Schmiz A, Hiemke C. Kavapyrone enriched extract from Piper methysticum as modulator of the GABA binding site in different regions of rat brain. Psychopharmacology (Berl). 1994;116(4):469-74.

73. Uebelhack R, Franke L, Schewe HJ. Inhibition of platelet MAO-B by kava pyrone-enriched extract from Piper methysticum Forster (kava-kava). Pharmacopsychiatry. 1998;31(5):187-92.

74. Wu D, Yu L, Nair M, et al. Cyclooxygenase enzyme inhibitory compounds with antioxidant activities from Piper methysticum (kava kava) roots. Phytomedicine. 2002;9:41-7.

75. Baum SS, Hill R, Rommelspacher H. Effect of kava extract and individual kavapyrones on neurotransmitter levels in the nucleus accumbens of rats. Prog Neuropsychopharmacol Biol Psychiatry. 1998;22(7):1105-20.

76. Seitz U, Schule A, Gleitz J. [3H]-monoamine uptake inhibition properties of kava pyrones. Planta Med. 1997;63(6):548-9.

77. Rex A, Morgenstern E, Fink H. Anxiolytic-like effects of kava-kava in the elevated plus maze test: a comparison with diazepam. Prog Neuropsychopharmacol Biol Psychiatry. 2002;26(5):855-60. 
78. Pittler $\mathrm{MH}$, Ernst E. Kava extract for treating anxiety. Cochrane Database Syst Rev. 2003(1):CD003383.

79. Sarris J, La Porte E, Schweitzer I. Kava: a comprehensive review of efficacy, safety, and psychopharmacology. Aust N Z J Psychiatry. 2011;45(1):27-35.

80. Sarris J, Kavanagh D, Byrne G, et al. The Kava Anxiety Depression Spectrum Study (KADSS): a randomized, placebo-controlled, cross-over trial using an aqueous extract of Piper methysticum. Psychopharmacology (Berl). 2009;205(3):399-407.

81. Sarris J, Scholey A, Schweitzer I, et al. The acute effects of kava and oxazepam on anxiety, mood, neurocognition, and genetic correlates: a randomized, placebo-controlled, double-blind study. Human Psychopharm 2012;27(3):262-9.

82. Teschke R, Sarris J, Glass $X$, et al. Kava, the anxiolytic herb: back to basics to prevent liver injury? Br J Clin Pharm. 2011;71(3):445-8.

83. Sarris J, Teschke R, Stough C, et al. Re-introduction of Kava (Piper methysticum) to the EU: is there a way forward? Planta Med. 2011;77(2):107-10.

84. Cases J, Ibarra A, Feuillere N, et al. Pilot trial of Melissa officinalis L. leaf extract in the treatment of volunteers suffering from mild-to-moderate anxiety disorders and sleep disturbances. Med J Nutrition Metab. 2011;4(3):211-218.

85. Awad R, Muhammad A, Durst T, et al. Bioassay-guided fractionation of lemon balm (Melissa officinalis L.) using an in vitro measure of GABA transaminase activity. Phytother Res. 2009;23(8):1075-81.

86. Awad R, Muhammad A, Durst T, et al. Bioassay-guided fractionation of lemon balm (Melissa officinalis L.) using an in vitro measure of GABA transaminase activity. Phytotherapy Res. 2009;23(8):1075-81.

87. Yoo DY, Choi JH, Kim W, et al. Effects of Melissa officinalis L.(Lemon Balm) extract on neurogenesis associated with serum corticosterone and GABA in the mouse dentate gyrus. Neurochem Res. 2011;36(2):250-7.

88. Ibarra A, Feuillere N, Roller M, et al. Effects of chronic administration of Melissa officinalis L. extract on anxiety-like reactivity and on circadian and exploratory activities in mice. Phytomedicine. 2010;17(6):397-403.

89. Lopez V, Martin S, Gomez-Serranillos MP, et al. Neuroprotective and neurological properties of Melissa officinalis. Neurochem Res. 2009;34(11):1955-61.

90. Kennedy DO, Scholey AB, Tildesley NTJ, et al. Modulation of mood and cognitive performance following acute administration of Melissa officinalis (lemon balm). Pharmacol Biochem Behav. 2002;72(4):953-64.

91. Kennedy DO, Little W, Scholey AB. Attenuation of laboratory-induced stress in humans after acute administration of Melissa officinalis (lemon balm). Psychosom Med. 2004;66(4):607-13.

92. Sayyah M, Boostani H, Pakseresht S, et al. Comparison of Silybum marianum (L.) Gaertn. with fluoxetine in the treatment of obsessive-compulsive disorder. Prog NeuroPsychopharmacol Biol Psychiatry. 2010;34(2):362-5.

93. Osuchowski MF, Johnson $\mathrm{VJ}, \mathrm{He} \mathrm{Q}$, et al. Alterations in regional brain neurotransmitters by silymarin, a natural antioxidant flavonoid mixture, in BALB/c mice. Pharm Biol. 2004;42(4-5):384-9.

94. Lu P, Mamiya T, Lu L, et al. Silibinin attenuates cognitive deficits and decreases of dopamine and serotonin induced by repeated methamphetamine treatment. Behav Brain Res. 2010;207(2):387-93.

95. Mazzio EA, Harris N, Soliman KFA. Food constituents attenuate monoamine oxidase activity and peroxide levels in C6 astrocyte cells. Planta Medica. 1998;64(7):603-6.

96. Akhondzadeh S, Naghavi HR, Vazirian M, et al. Passionflower in the treatment of generalized anxiety: a pilot double-blind randomized controlled trial with oxazepam. J Clin Pharm Ther. 2001;26(5):363-7.

97. Dhawan K, Kumar S, Sharma A. Anxiolytic activity of aerial and underground parts of Passiflora incarnata. J Ethnopharmacol. 2001;72(8):922-6. 
98. Dhawan K, Kumar S, Sharma A. Comparative biological activity study on Passiflora incarnata and P. edulis. Fitoterapia. 2001;72(6):698-702.

99. Awad R, Arnason JT, Trudeau V, et al. Phytochemical and biological analysis of skullcap (Scutellaria lateriflora L.): a medicinal plant with anxiolytic properties. Phytomedicine.

2003;10(8):640-9.

100. Dhawan K, Kumar S, Sharma A. Anti-anxiety studies on extracts of Passiflora incarnata linneaus. J Ethnopharmacol. 2001;78(2-3):165-70.

101. Brown E, Hurd NS, McCall S, et al. Evaluation of the anxiolytic effects of chrysin, a Passiflora incarnata extract, in the laboratory rat. AANA J. 2007;75(5):333-7.

102. de Castro PCF, Hoshino A, Silva JCd, et al. Possible anxiolytic effect of two extracts of Passiflora quadrangularis L. in experimental models. Phytotherapy Res. 2007;21(5):481-4.

103. Wolfman C, Viola H, Paladini A, et al. Possible anxiolytic effects of chrysin, a central benzodiazepine receptor ligand isolated from Passiflora coerulea. Pharmacol Biochem Behav. 1994;47(1):1-4.

104. Sampath C, Holbik M, Krenn L, et al. Anxiolytic effects of fractions obtained from Passiflora incarnata L. in the elevated plus maze in mice. Phytotherapy Res. 2011;25(6):789-95.

105. Dhawan K, Kumar S, Sharma A. Comparative anxiolytic activity profile of various preparations of Passiflora incarnata linneaus: a comment on medicinal plants' standardization. J Altern Comp Med. 2002;8(3):283-91.

106. Movafegh A, Alizadeh R, Hajimohamadi F, et al. Preoperative oral Passiflora incarnata reduces anxiety in ambulatory surgery patients: a double-blind, placebo-controlled study. Anesth Analg. 2008;106(6):1728-32.

107. Aslanargun P, Cuvas O, Dikmen B, et al. Passiflora incarnata Linneaus as an anxiolytic before spinal anesthesia. J Anesth. 2012;26(1):39-44.

108. Appel K, Rose T, Fiebich $B$, et al. Modulation of the $\gamma$-aminobutyric acid (GABA) system by Passiflora incarnata L. Phytotherapy Res. 2011;25(6):838-43.

109. Petry RD, Reginatto F, de-Paris F, et al. Comparative pharmacological study of hydroethanol extracts of Passiflora alata and Passiflora edulis leaves. Phytotherapy Res. 2001;15(2):162-4.

110. Grundmann O, Wahling C, Staiger C, et al. Anxiolytic effects of a passion flower (Passiflora incarnata L.) extract in the elevated plus maze in mice. Die Pharmazie 2009;64(1):63-4.

111. Grundmann O, Wang J, McGregor GP, et al. Anxiolytic activity of a phytochemically characterized Passiflora incarnata extract is mediated via the GABAergic system. Planta Med. 2008;74(15):1769-73.

112. Barbosa PR, Valvassori SS, Bordignon CL, et al. The aqueous extracts of Passiflora alata and Passiflora edulis reduce anxiety-related behaviors without affecting memory process in rats. J Medicinal Food. 2008;11(2):282-8.

113. Deng J, Zhou Y, Bai M, et al. Anxiolytic and sedative activities of Passiflora edulis f. flavicarpa. J Ethnopharmacol. 2010;128(1):148-53.

114. Li H, Zhou P, Yang Q, et al. Comparative studies on anxiolytic activities and flavonoid compositions of Passiflora edulis 'edulis' and Passiflora edulis 'flavicarpa'. J Ethnopharmacol. 2011;133(3):1085-90.

115. Lolli LF, Sato CM, Romanini CV, et al. Possible involvement of GABAA-benzodiazepine receptor in the anxiolytic-like effect induced by Passiflora actinia extracts in mice. J Ethnopharmacol. 2007;111(2):308-14.

116. Soulimani R, Younos C, Jarmouni S, et al. Behavioural effects of Passiflora incarnata L. and its indole alkaloid and flavonoid derivatives and maltol in the mouse. J Ethnopharmacol. 1997;57(1):1120.

117. Akhondzadeh S, Naghavi HR, Vazirian M, et al. Passionflower in the treatment of generalized anxiety: a pilot double-blind randomized controlled trial with oxazepam. J Clin Pharm Ther.

2001;26(5):363-7. 
118. Movafegh A, Alizadeh R, Hajimohamadi F, et al. Preoperative oral Passiflora incarnata reduces anxiety in ambulatory surgery patients: a double-blind, placebo-controlled study. Anesth Analg. 2008;106(6):1728-32.

119. Panossian A, Gabrielian E, Wagner H. On the mechanism of action of plant adaptogens with particular reference to Cucurbitacin R Diglucoside. Phytomedicine. 1999;6(3):147-55.

120. Panossian A, Wikman G, Sarris J. Rosenroot (Rhodiola rosea): traditional use, chemical composition, pharmacology and clinical efficacy. Phytomedicine. 2010;17(7):481-93.

121. Perfumi M, Mattioli L. Adaptogenic and central nervous system effects of single doses of $3 \%$ rosavin and $1 \%$ salidroside Rhodiola rosea L. extract in mice. Phytother Res. 2007;21(1):37-43.

122. Bystritsky A, Kerwin L, Feusner JD. A pilot study of Rhodiola rosea (Rhodax) for generalized anxiety disorder (GAD). J Altern Complement Med. 2008;14(2):175-80.

123. Perry NSL, Houghton PJ, Sampson J, et al. In-vitro activity of S. lavandulaefolia (Spanish sage) relevant to treatment of Alzheimer's disease. J Pharm Pharmacol. 2001;53(10):1347-56.

124. Kennedy DO, Dodd FL, Robertson BC, et al. Monoterpenoid extract of sage (Salvia lavandulaefolia) with cholinesterase inhibiting properties improves cognitive performance and mood in healthy adults. J Psychopharmacol. 2011;25(8):1088-100.

125. Herrera-Ruiz M, García-Beltrán Y, Mora S, et al. Antidepressant and anxiolytic effects of hydroalcoholic extract from Salvia elegans. J Ethnopharmacol. 2006;107(1):53-8.

126. Hosseinzadeh H, Danaee A, Ziaee T. Anti-anxiety effect of aqueous and ethanolic extracts of Salvia leriifolia Benth. leaves in mice using elevated plus maze. J Medicinal Plant. 2008;7(27):25-36.

127. Rabbani M, Sajjadi SE, Jafarian A, et al. Anxiolytic effects of Salvia reuterana Boiss. on the elevated plus-maze model of anxiety in mice. J Ethnopharmacol. 2005;101(1-3):100-3.

128. Kennedy DO, Pace S, Haskell C, et al. Effects of cholinesterase inhibiting sage (Salvia officinalis) on mood, anxiety and performance on a psychological stressor battery.

Neuropsychopharmacology. 2006;31(4):845-52.

129. Tildesley NTJ, Kennedy DO, Perry EK, et al. Positive modulation of mood and cognitive performance following administration of acute doses of Salvia lavandulaefolia essential oil to healthy young volunteers. Physiol Behav. 2005;83(5):699-709.

130. Wolfson P, Hoffmann D. An investigation into the efficacy of Scutellaria lateriflora in healthy volunteers. Altern Ther Health Med. 2003;9(2):74.

131. Li J, Wang Y-H, Smillie TJ, et al. Identification of phenolic compounds from Scutellaria lateriflora by liquid chromatography with ultraviolet photodiode array and electrospray ionization tandem mass spectrometry. J Pharml Biomed Anal. 2012;63:120-7.

132. Zhang Z, Lian X-Y, Li S, et al. Characterization of chemical ingredients and anticonvulsant activity of American skullcap (Scutellaria lateriflora). Phytomedicine. 2009;16(5):485-93.

133. Kuroda M, Iwabuchi K, Mimaki Y. Chemical constituents of the aerial parts of Scutellaria lateriflora and their alpha-glucosidase inhibitory activities. Natural Product Commun. 2012;7(4):471.

134. Yaghmai MS. Volatile constituents of Scutellaria lateriflora L. Flavour Fragrance J. 1988;3(1):27-31.

135. de Carvalho RSM, Duarte FS, de Lima TCM. Involvement of GABAergic non-benzodiazepine sites in the anxiolytic-like and sedative effects of the flavonoid baicalein in mice. Behav Brain Res. 2011;221(1):75-82.

136. Hui KM, Huen MSY, Wang HY, et al. Anxiolytic effect of wogonin, a benzodiazepine receptor ligand isolated from Scutellaria baicalensis Georgi. Biochem Pharmacol. 2002;64(9):1415-24.

137. Wolfson P, Hoffmann D. An investigation into the efficacy of Scutellaria lateriflora in healthy volunteers. Altern Ther Health Med. 2003;9(2):74.

138. Rahimi R, Nikfar S, Abdollahi M. Efficacy and tolerability of Hypericum perforatum in major depressive disorder in comparison with selective serotonin reuptake inhibitors: a meta-analysis. Prog Neuropsychopharmacol Biol Psychiatry. 2009;33(1):118-27.

139. Butterweck V, Schmidt M. St. John's wort: role of active compounds for its mechanism of action and efficacy. Wiener Medizinische Wochenschrift. 2007;157(13-14):356-61. 
140. Nathan PJ. Hypericum perforatum (St John's Wort): a non-selective reuptake inhibitor? A review of the recent advances in its pharmacology. J Psychopharmacol. 2001;15(1):47-54.

141. Taylor LH, Kobak KA. An open-label trial of St. John's Wort (Hypericum perforatum) in obsessive-compulsive disorder. J Clin Psychiatry. 2000;61(8):575-8.

142. Kobak KA, Taylor LV, Bystritsky A, et al. St John's wort versus placebo in obsessivecompulsive disorder: results from a double-blind study. Int Clin Psychopharmacol. 2005;20(6):299304.

143. Kobak KA, Taylor LV, Warner G, et al. St. John's wort versus placebo in social phobia: results from a placebo-controlled pilot study. J Clin Psychopharmacol. 2005;25(1):51-8.

144. Gao XQ, Björk L. Valerenic acid derivatives and valepotriates among individuals, varieties and species of Valeriana. Fitoterapia. 2000;71(1):19-24.

145. Patočka J, Jakl J. Biomedically relevant chemical constituents of Valeriana officinalis. J Appl Biomed. 2010;8:11-18.

146. Muller CE, Schumacher B, Brattstrom A, et al. Interactions of valerian extracts and a fixed valerian-hop extract combination with adenosine receptors. Life Sci. 2002;71(16):1939-49.

147. Benke $D$, Barberis $A$, Kopp $S$, et al. GABA(A) receptors as in vivo substrate for the anxiolytic action of valerenic acid, a major constituent of valerian root extracts. Neuropharmacology. 2009;56(1):174-81.

148. Dunayev VV, Trzhetsinsky SD, Tishkin VS, et al. Biological activity of the sum of valepotriates isolated from Val. alliariifolia Adams. Farmakologiya i Toksikologiya. 1987;50(6):33-7.

149. Andreatini R, Leite JR. Effect of valepotriates on the behavior of rats in the elevated plusmaze during diazepam withdrawal. Eur J Pharmacol. 1994;260(2-3):233-5.

150. Miyasaka LS, Atallah AN, Soares BG. Valerian for anxiety disorders. Cochrane Database Syst Rev. 2006(4):CD004515.

151. Andreatini R, Sartori VA, Seabra MLV, et al. Effect of valepotriates (valerian extract) in generalized anxiety disorder: a randomized placebo-controlled pilot study. Phytotherapy Res. 2002;16(7):650-4.

152. Bos R, Hendriks H, Scheffer JJC, et al. Cytotoxic potential of valerian constituents and valerian tinctures. Phytomedicine. 1998;5(3):219-25.

153. Bounthanh C, Bergmann C, Beck JP, et al. Valepotriates, a new class of cytotoxic and antitumor agents. Planta Medica. 1981;41(1):21-8.

154. Bhattacharyya D, Jana U, Debnath PK, et al. Initial exploratory observational pharmacology of Valeriana wallichii on stress management: a clinical report. NMCJ. 2007;9(1):36-9.

155. Griffiths RR, Johnson MW, Richards WA, et al. Psilocybin occasioned mystical-type experiences: immediate and persisting dose-related effects. Psychopharmacology. 2011;218(4):64965.

156. Passie T, Seifert J, Schneider U, et al. The pharmacology of psilocybin. Addict Biol. 2002;7(4):357-64.

157. Studerus E, Kometer M, Hasler F, et al. Acute, subacute and long-term subjective effects of psilocybin in healthy humans: a pooled analysis of experimental studies. J Psychopharmacol. 2011;25(11):1434-52.

158. Halberstadt AL, Geyer MA. Multiple receptors contribute to the behavioral effects of indoleamine hallucinogens. Neuropharmacology. 2011;61(3):364-81.

159. Vollenweider FX, Vollenweider-Scherpenhuyzen MFI, Bäbler A, et al. Psilocybin induces schizophrenia-like psychosis in humans via a serotonin-2 agonist action. NeuroReport. 1998;9(17):3897-902.

160. Frokjaer VG, Mortensen EL, Nielsen FÅ, et al. Frontolimbic serotonin $2 A$ receptor binding in healthy subjects is associated with personality risk factors for affective disorder. Biol Psychiatry. 2008;63(6):569-76.

161. Vollenweider FX, Kometer M. The neurobiology of psychedelic drugs: implications for the treatment of mood disorders. Nature Rev Neurosci. 2010;11(9):642-51. 
162. Grof S, Goodman L, Richards W, et al. LSD-assisted psychotherapy in patients with terminal cancer. Int Pharmacophsychiatry. 1973;8:129-44.

163. Grob CS, Danforth AL, Chopra GS, et al. Pilot study of psilocybin treatment for anxiety in patients with advanced-stage cancer. Arch Gen Psychiatry. 2011;68(1):71-8.

164. Brandrup E, Vanggaard T. LSD treatment in a severe case of compulsive neurosis. Acta Psychiatrica Scandinavica. 1977;55(2):127-41.

165. Moreno FA, Delgado PL. Hallucinogen-induced relief of obsessions and compulsions. Am J Psychiatry. 1997;154(7):1037-8.

166. Moreno FA, Wiegand CB, Taitano EK, et al. Safety, tolerability, and efficacy of psilocybin in 9 patients with obsessive-compulsive disorder. J Clin Psychiatry. 2006;67(11):1735-40.

167. Matsushima Y, Shirota O, Kikura-Hanajiri R, et al. Effects of psilocybe argentipes on marbleburying behavior in mice. Biosci Biotechnol Biochem. 2009;73(8):1866-8.

168. Dobkin De Ríos M. Visionary vine: psychedelic healing in the Peruvian Amazon. Int J Soc Psychiatry. 1972;17:256-69.

169. McKenna DJ. Clinical investigations of the therapeutic potential of ayahuasca: rationale and regulatory challenges. Pharmacol Ther. 2004;102(2):111-29.

170. Riba J, Valle M, Urbano G, et al. Human pharmacology of ayahuasca: subjective and cardiovascular effects, monoamine metabolite excretion, and pharmacokinetics. J Pharmacol Exp Ther. 2003;306(1):73-83.

171. Grob CS, McKenna DJ, Callaway JC, et al. Human psychopharmacology of hoasca, a plant hallucinogen used in ritual context in Brazil. J Nerv Ment Dis. 1996;184(2):86-94.

172. Callaway JC, Airaksinen MM, McKenna DJ, et al. Platelet serotonin uptake sites increased in drinkers of ayahuasca. Psychopharmacology. 1994;116(3):385-7.

173. Santos RG, Landeira-Fernandez J, Strassman RJ, et al. Effects of ayahuasca on psychometric measures of anxiety, panic-like and hopelessness in Santo Daime members. J Ethnopharmacol.

2007;112(3):507-13.

174. Patton GC, Coffey C, Carlin JB, et al. Cannabis use and mental health in young people: cohort study. BMJ. 2002;325(7374):1195-8.

175. Moore TH, Zammit S, Lingford-Hughes A, et al. Cannabis use and risk of psychotic or affective mental health outcomes: a systematic review. Lancet. 2007;370(9584):319-28.

176. Campos AC, Guimarães FS. Involvement of 5HT1A receptors in the anxiolytic-like effects of cannabidiol injected into the dorsolateral periaqueductal gray of rats. Psychopharmacology. 2008;199(2):223-30.

177. Resstel LBM, Tavares RF, Lisboa SFS, et al. 5-HT1A receptors are involved in the cannabidiolinduced attenuation of behavioural and cardiovascular responses to acute restraint stress in rats. $\mathrm{Br}$ J Pharmacol. 2009;156(1):181-8.

178. Bergamaschi MM, Queiroz RHC, Chagas MHN, et al. Cannabidiol reduces the anxiety induced by simulated public speaking in treatment-nave social phobia patients. Neuropsychopharmacology. 2011;36(6):1219-26.

179. Zuardi AW, Cosme RA, Graeff FG, et al. Effects of ipsapirone and cannabidiol on human experimental anxiety. J Psychopharmacol. 1993;7(1):82-8.

180. Griffiths RR, Grob CS. Hallucinogens as medicine. Scientific American. 2010;303(6):77-9.

181. Ulrich-Merzenich $\mathrm{G}$, Zeitler $\mathrm{H}$, Jobst $\mathrm{D}$, et al. Application of the "Omic" technologies in phytomedicine. Phytomedicine. 2007;14(1):70-82.

182. Sarris J, Ng C, Schweitzer I. "Omic" genetic technologies for herbal medicines in psychiatry. Phytother Res. 2012;26(4):522-7. 
Table 1 Anxiolytic plant medicines: clinical studies

\begin{tabular}{|c|c|c|c|c|c|c|}
\hline Botanical name & $\begin{array}{c}\text { Active } \\
\text { constituents }^{\mathrm{a}} \\
\end{array}$ & $\begin{array}{c}\text { Conditions } \\
\text { indicated }\end{array}$ & $\begin{array}{c}\text { Neurotransmitter } \\
\text { systems }^{\mathrm{b}}\end{array}$ & Method summary & Results & References \\
\hline $\begin{array}{l}\text { Bacopa monnieri } \\
\text { (brahmi) }\end{array}$ & Bacoside A & General anxiety & ACh, DA, NA, 5-HT & $\begin{array}{l}\text { 12-week DB RCT } 300 \mathrm{mg} / \text { day }(n=54, \mathrm{CP}) \\
\text { 12-week DB RCT } 300 \mathrm{mg} / \text { day }(n=46, \mathrm{HV})\end{array}$ & $\begin{array}{l}\text { STAI } \downarrow^{*} \\
\text { STAI } \downarrow^{*}\end{array}$ & $(25,28-30)$ \\
\hline $\begin{array}{l}\text { Cannabis sativa/indica } \\
\text { (marijuana) }\end{array}$ & Cannabidiol & Social phobia & Cannabinoid & Acute DB RCT $600 \mathrm{mg}(n=24, \mathrm{CP})$ & VAS-Anx $\downarrow *$ & $(176-178)$ \\
\hline $\begin{array}{l}\text { Citrus aurantium } \\
\text { (bitter orange) }\end{array}$ & $\begin{array}{l}\text { Volatile oils, } \\
\text { flavonoids }\end{array}$ & General anxiety & GABA & Acute DB RCT $1 \mathrm{ml} / \mathrm{kg} \quad(n=60, \mathrm{CP})$ & $\begin{array}{l}\text { STAI-S } \downarrow \text { ns } \\
\text { APAIS } \downarrow \text { ns }\end{array}$ & $(32,33)$ \\
\hline $\begin{array}{l}\text { Echinacea spp. } \\
\text { (purple cone flower) }\end{array}$ & Alkylamides & General anxiety & Cannabinoid & 1-week OLT 20, 40 mg/day ( $n=31, \mathrm{HV})$ & STAI $\downarrow+$ & $(40-43)$ \\
\hline $\begin{array}{l}\text { Galphimia glauca } \\
\text { (Galphimia) }\end{array}$ & $\begin{array}{l}\text { Nor-seco-triterpene } \\
\text { (galphimine B) }\end{array}$ & GAD & $5-\mathrm{HT}$ & $\begin{array}{l}\text { 4-week DB RCT } 620 \text { mg/day vs bzd } 2 \mathrm{mg} / \text { day ( } n=153 \text {, } \\
\text { CP) } \\
\text { 15-week DB RCT } 0.75-1.5 \mathrm{~g} / \text { day vs. bzd } 1-2 \mathrm{mg}(n=191 \text {, } \\
\text { CP) }\end{array}$ & $\begin{array}{l}\text { HAMA } \downarrow= \\
\text { HAMA } \downarrow *\end{array}$ & $(47-51)$ \\
\hline $\begin{array}{l}\text { Ginkgo biloba } \\
\text { (EGb 761) }\end{array}$ & Ginkgolides & GAD & $\mathrm{DA}, \mathrm{NE}$ & 4-week DB RCT 240, $480 \mathrm{mg} /$ day $(n=107, \mathrm{CP})$ & HAMA $\downarrow^{*}$ & $(57-60)$ \\
\hline $\begin{array}{l}\text { Hypericum perforatum } \\
\text { (St. John's wort) }\end{array}$ & $\begin{array}{l}\text { Hyperforin, } \\
\text { hypericin, } \\
\text { pseudohypericin }\end{array}$ & OCD, Social Phobia & 5-HT, NA, DA, MAO & $\begin{array}{l}\text { OCD: } 12 \text {-wk OLT } 2.7 \mathrm{mg} \text { hypericin/day }(n=12, \mathrm{CP}) \\
\text { 12-week DB RCT 600-1800 mg/day }(n=60, \mathrm{CP}) \\
\text { SP: } 12 \text {-week DB RCT } 600-1800 \mathrm{mg} / \text { day }(n=40, \mathrm{CP})\end{array}$ & $\begin{array}{l}\text { YBOCS } \downarrow \Delta+ \\
\text { YBOCS } \downarrow \text { ns } \\
\text { LSAS ns }\end{array}$ & $(139-141)$ \\
\hline Matricaria recutita & Flavonoids (apigenin) & GAD & GABA, GABA-T & 8-week DB RCT 220-1100 mg/day $(n=57$, CP) & HAMA $\downarrow^{*}$ & $(48-50)$ \\
\hline
\end{tabular}


(Chamomile) 


\begin{tabular}{|c|c|c|c|c|c|c|}
\hline $\begin{array}{l}\text { Melissa officinalis } \\
\text { (lemon balm) }\end{array}$ & $\begin{array}{l}\text { Flavonoids, volatile } \\
\text { oils, triterpenes }\end{array}$ & $\begin{array}{l}\text { General anxiety and } \\
\text { sleep disorder }\end{array}$ & GABA, GABA-T & 15-day OLT $600 \mathrm{mg} /$ day $(n=20, \mathrm{HV})$ & FRSA $\downarrow^{\dagger}$ & $(84,85)$ \\
\hline $\begin{array}{l}\text { Passiflora incarnata } \\
\text { (passionflower) }\end{array}$ & $\begin{array}{l}\text { Amino acids, chrysin, } \\
\text {-carboline alkaloids, } \\
\text { flavonoids }\end{array}$ & $\begin{array}{l}\text { GAD; pre-surgery } \\
\text { anxiety }\end{array}$ & GABA & $\begin{array}{l}\text { Acute DB RCT } 700 \mathrm{mg} / 5 \mathrm{ml}(n=60, \mathrm{HV}) \\
\text { Acute DB RCT } 500 \mathrm{mg}(n=60, \mathrm{HV}) ; \\
\text { 4-week DB RCT } 45 \text { drops vs. oxazepam }(n=36, \mathrm{CP})\end{array}$ & $\begin{array}{l}\text { STAI-S } \downarrow * \\
\text { Anx NRS } \downarrow^{*} \\
\text { HAMA } \downarrow=\end{array}$ & $\begin{array}{l}(107,117, \\
118)\end{array}$ \\
\hline $\begin{array}{l}\text { Piper methysticum } \\
\text { (kava) }\end{array}$ & $\begin{array}{l}\text { Kavalactones (mainly } \\
\text { kavain and } \\
\text { dihydrokavain) }\end{array}$ & $\begin{array}{l}\text { GAD (many studies } \\
\text { involve multiple } \\
\text { anxiety disorders) }\end{array}$ & GABA, DA, NA, MAO & $\begin{array}{l}\text { Meta-analysis ( } 7 \text { chronic RCTs, } n=345, \mathrm{CP} \text { ) } \\
60-240 \text { mg kavalactones, } 6-8 \text { weeks duration }\end{array}$ & HAMA $\downarrow *$ & $(8,78-80)$ \\
\hline $\begin{array}{l}\text { Psilocybe spp. } \\
\text { (psilocybin) }\end{array}$ & $\begin{array}{l}\text { 4-Phosphoryloxy- } \\
\text { dimethyltryptamine }\end{array}$ & $\begin{array}{l}\text { Anxiety in terminally } \\
\text { ill; OCD }\end{array}$ & 5-HT & $\begin{array}{l}\text { Terminal illness: acute DB RCT } 200 \mu \mathrm{g} / \mathrm{kg}(n=12, \mathrm{CP}) \text {; } \\
\text { chronic OLT 6-month follow-up. } \\
\text { OCD: Acute OLT 25-300 } \mu \mathrm{g} / \mathrm{kg}(n=9, \mathrm{CP})\end{array}$ & $\begin{array}{l}\text { POMS } \downarrow \text { ns } \\
\text { STAI-T } \downarrow+ \\
\text { YBOCS } \downarrow \dagger\end{array}$ & $\begin{array}{l}(155,157- \\
159,161 \\
163,165- \\
167)\end{array}$ \\
\hline $\begin{array}{l}\text { Psychotria } \\
\text { viridis/Banisteriopsis } \\
\text { caapi } \\
\text { (ayahuasca, hoasca) }\end{array}$ & $\begin{array}{l}\mathrm{N}, \mathrm{N}- \\
\text { dimethyltryptamine }\end{array}$ & $\begin{array}{l}\text { Impulse control; } \\
\text { panic }\end{array}$ & 5-HT & $\begin{array}{l}\text { Long-term user cohort study }(n=30, \mathrm{HV}) \text {; } \\
\text { Acute DB RCT } 50 \mathrm{ml} \text { ayahuasca }(n=9, \mathrm{HV})\end{array}$ & $\begin{array}{l}\text { ImpCon } \uparrow \Delta \\
\text { PRS } \downarrow * \text { STAI } \\
\downarrow \text { ns }\end{array}$ & $(169-173)$ \\
\hline $\begin{array}{l}\text { Rhodiola rosea } \\
\text { (roseroot) }\end{array}$ & $\begin{array}{l}\text { Pheylpropane } \\
\text { compounds } \\
\text { (rosavins) and } \\
\text { phenylethane } \\
\text { derivatives } \\
\text { (salidroside) }\end{array}$ & $\begin{array}{l}\text { GAD, comorbid } \\
\text { depression }\end{array}$ & $\begin{array}{l}\text { Monoamines. HPA } \\
\text { axis, MAO }\end{array}$ & 10-week OLT 340 mg/day ( $n=10$, CP) & $\begin{array}{l}\text { HAMA } \downarrow+ \\
\text { 4DADS } \downarrow+\end{array}$ & $(120-122)$ \\
\hline
\end{tabular}




\begin{tabular}{|c|c|c|c|c|c|c|}
\hline $\begin{array}{l}\text { Salvia spp. } \\
\text { (sage) }\end{array}$ & $\begin{array}{l}\text { Terpenoids (including } \\
\text { a-pinene, b-pinene, } \\
\text { 1,8-cineole, thujone, } \\
\text { camphor and } \\
\text { geraniol) }\end{array}$ & General anxiety & $\begin{array}{l}\text { ACh } \\
\text { (cognitive-enhancing } \\
\text { effects) }\end{array}$ & Acute DB RCT 300, $600 \mathrm{mg}(n=30, \mathrm{HV})$ & STAI-S $\downarrow^{*}$ & $\begin{array}{l}(44,123- \\
129)\end{array}$ \\
\hline $\begin{array}{l}\text { Scutellaria lateriflora } \\
\text { (skullcap) }\end{array}$ & $\begin{array}{l}\text { Scutelaterin } A \text {, } \\
\text { baicalin }\end{array}$ & General anxiety & $\begin{array}{l}\text { GABA, GABA-T, } \\
5-\mathrm{HT}\end{array}$ & $\begin{array}{l}\text { Acute DB crossover RCT } 100 / 200 / 350 \mathrm{mg} / \text { day } \\
(n=19, \mathrm{HV})\end{array}$ & APASRS $\downarrow \Delta$ & $\begin{array}{l}(99,131- \\
134,136 \\
137)\end{array}$ \\
\hline $\begin{array}{l}\text { Silybum marianum } \\
\text { (milk thistle) }\end{array}$ & $\begin{array}{l}\text { Flavonolignans } \\
\text { (silymarin) }\end{array}$ & OCD & 5-HT, MAO & 8-week DB RCT $600 \mathrm{mg} /$ day vs. fluoxetine $(n=35, \mathrm{CP})$ & Y-BOCS $\downarrow=$ & $(92,93,95)$ \\
\hline $\begin{array}{l}\text { Valeriana spp. } \\
\text { (Valerian) }\end{array}$ & $\begin{array}{l}\text { Valarenic acid, } \\
\text { valepotriates }\end{array}$ & General anxiety & Adenosine, GABA & $\begin{array}{l}\text { 4-week DB RCT } 81.3 \mathrm{mg} / \text { day valepotriates vs. } \\
\text { diazepam } 6.5 \mathrm{mg} / \text { day (mean dose); or placebo }(n=36 \text {, } \\
\text { CP); } \\
\text { 8-week OLT } 1000 \mathrm{mg} / \text { day }(n=33, \mathrm{HV})\end{array}$ & $\begin{array}{l}\text { HAMA ns } \\
\text { STAI-T ns } \\
\text { BPRS } \downarrow^{\dagger}\end{array}$ & $\begin{array}{l}(147,149- \\
151,154)\end{array}$ \\
\hline $\begin{array}{l}\text { Withania somnifera } \\
\text { (ashwagandha) }\end{array}$ & Glycowithanolides & General anxiety & GABA & 6-week DB RCT 1-2.5g/day ( $n=39, \mathrm{CP})$ & HAMA ns & $(22)$ \\
\hline
\end{tabular}

a Constituents to date found to have relevant biological activity

b Mechanism/s of action revealed in preclinical trials

4DADS Four Dimensional Anxiety and Depression Scale, 5-HT 5-hydroxytryptamine; serotonin, ACh acetyl cholinesterase, Anx NRS Anxiety Numeric Rating Scale, APAIS Amsterdam Preoperative Anxiety and Information Scale, APASRS Acute Psycho-Activity Self-Rating Scale, BDNF brain-derived neurotropic factor, $B P R S$ Brief Psychiatric Rating Scale, $C P$ clinical population, $D A$ dopamine, $D B$ double-blind, $F R S A$ Free Rating Scale for Anxiety, GABA Y-aminobutyric acid, $G A B A-T$-aminobutyric acid-transaminase, GAD generalized anxiety disorder, Glu glutamate, HAMA Hamilton Anxiety Rating Scale, HPA axis hypothalmic pituitary adrenal axis, HV healthy volunteers, ImpCon impulse control,

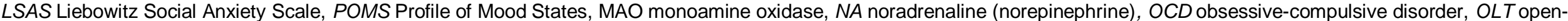
label trial, PRS panic-related signs, RCT randomized controlled trial, STAI State-Trait Anxiety Inventory, STAI-T State-Trait Anxiety Inventory-Trait, STAI-S State-Trait Anxiety Inventory-State, VAS-Anx Visual-Analogue Scale Anxiety, $Y$-BOCS Yale-Brown Obsessive Compulsive Scale, $\downarrow$ decreased, $\uparrow$ increased, * significant $(p<0.05$ treatment $\times$ time interaction), ns not significant, = equivalent to positive control, $\uparrow$ significant reduction $(p<0.05)$ in an OLT, $\Delta$ statistical significance not reported 
